Illinois State University

ISU ReD: Research and eData

Theses and Dissertations

$5-25-2015$

\title{
Can We Do Better When Students Are A Threat To Self? A Review Of Legal And Policy Implications For Current Practices On College Campuses
}

Jennifer Ann Hemingway

Illinois State University, jenhem@gmail.com

Follow this and additional works at: https://ir.library.illinoisstate.edu/etd

Part of the Education Policy Commons, Higher Education Administration Commons, and the Higher Education and Teaching Commons

\section{Recommended Citation}

Hemingway, Jennifer Ann, "Can We Do Better When Students Are A Threat To Self? A Review Of Legal And Policy Implications For Current Practices On College Campuses" (2015). Theses and Dissertations. 423. https://ir.library.illinoisstate.edu/etd/423

This Dissertation is brought to you for free and open access by ISU ReD: Research and eData. It has been accepted for inclusion in Theses and Dissertations by an authorized administrator of ISU ReD: Research and eData. For more information, please contact ISUReD@ilstu.edu. 


\title{
CAN WE DO BETTER WHEN STUDENTS ARE A THREAT TO SELF? A REVIEW OF LEGAL AND POLICY IMPLICATIONS FOR CURRENT PRACTICES ON COLLEGE CAMPUSES
}

\author{
Jennifer A. Hemingway
}

122 Pages

August 2015

Many colleges/universities believe that a student who is a threat to self increases campus risk and liability (Appelbaum, 2006; Massie, 2008; Pavela, 2006 \& 2010). This study uses integrated policy analysis to (1) define the policy problem regarding college students who are a threat to self; (2) analyze the current legal opinion of the courts regarding institutional liability when college students are a threat to self; (3) examine the 2010 change to the direct threat provision in Title II legislation; (4) determine the implications for institutional policies and practices. The analysis illustrates, according to the courts and changes in Title II legislation, the true increase in risk and liability occurs when colleges/universities do not proactively plan for and support students who are a threat to self. 
CAN WE DO BETTER WHEN STUDENTS ARE A THREAT TO SELF?

A REVIEW OF LEGAL AND POLICY IMPLICATIONS FOR

CURRENT PRACTICES ON COLLEGE CAMPUSES

JENNIFER A. HEMINGWAY

A Dissertation Submitted in Partial

Fulfillment of the Requirements

for the Degree of

DOCTOR OF PHILOSOPHY

Department of Educational Administration and Foundations

ILLINOIS STATE UNIVERSITY

2015 
C 2015 Jennifer A. Hemingway 
CAN WE DO BETTER WHEN STUDENTS ARE A THREAT TO SELF?

A REVIEW OF LEGAL AND POLICY IMPLICATIONS FOR

CURRENT PRACTICES ON COLLEGE CAMPUSES

JENNIFER A. HEMINGWAY

COMMITTEE MEMBERS:

Elizabeth T. Lugg, Chair

Diane R. Dean

Wendy G. Troxel

Tracy L. Davis 


\section{ACKNOWLEDGMENTS}

My parents, Ray and Coletta Wassum, passed away early in my Ph.D. journey. Although they will not see me hooded, I owe my strength, resilience, curiosity and persistence to them. I wish to thank my husband, John Hemingway, for encouraging me and supporting me on this journey.

Thank you to my committee for challenging me to do my best. To Dr. Lugg for agreeing to be my advisor on the first day of Higher Ed Law. To Dr. Davis for asking me to be involved in CSMMD and agreeing to serve on my committee. To Dr. Dean for letting me play with ideas in class and providing encouraging and constructive feedback. To Dr. Troxel for pushing me to write in a scholarly fashion. Thank you to my cohort. You made class weekends at Illinois State University thought provoking and fun.

Last but not least, thank you to the Randolph Street Irregulars. A great bunch of people who helped me laugh when I wanted to cry; kept me going when it would be easy to stop and above all believed I would do it.

J.A.H. 


\section{CONTENTS}

\section{Page}

ACKNOWLEDGMENTS

TABLES

\section{CHAPTER}

I. REASEARCH PROBLEM AND ITS BACKGROUND

The Perfect Storm

Research Problem

Research Questions

Definitions

Limitations

II. REVIEW OF LITERATURE 5

Student Behavior: A Historical Concern 5

Identifying Disturbing Students $\quad 9$

Millennial Students and Mental Health 12

$\begin{array}{ll}\text { Gender and Mental Health } & 14\end{array}$

$\begin{array}{ll}\text { Behavior that is a Threat to Self } & 18\end{array}$

$\begin{array}{ll}\text { Eating Disorders } & 18\end{array}$

Nonsuicidal Self-Injury $\quad 18$

College Student Suicide $\quad 19$

Addressing Student Well-Being 20

Institutional Duty 20

Can Colleges/Universities Do Better? 25 
III. METHODOLOGY 26

Define the Problem 28

Assemble the Evidence $\quad 29$

Construct the Alternatives $\quad 31$

Select the Criteria 31

Project the Outcomes 34

IV. COLLEGE/UNIVERSITY LIABILITY WHEN A STUDENT IS A THREAT TO SELF 37

Jain v. State of Iowa 39

$\begin{array}{ll}\text { Analysis } & 40\end{array}$

Schieszler v. Ferrum College $\quad 41$

$\begin{array}{ll}\text { Analysis } & 42\end{array}$

Shin v. Massachusetts Institute of Technology 43

Analysis $\quad 44$

Mahoney v. Allegheny College 45

$\begin{array}{ll}\text { Analysis } & 47\end{array}$

Bash v. Clark College 48

$\begin{array}{ll}\text { Analysis } & 49\end{array}$

Did The Courts Err in Schieszler and Shin? 50

$\S 314$ v. $\S 323$ Restatement (Second) of Torts 50

Balancing Foreseeability and Burden $\quad 51$

Limited Precedential Value $\quad 52$

Message in Mahoney 53

V. TITLE II OF THE AMERICANS WITH DISABILITIES ACT AND SECTION 504 OF THE REHABILITATION ACT OF 1973

Nott v. George Washington University 55

Title II of the Americans with Disabilities Act and

Section 504 of the Rehabilitation Act of 1973 
Individualized Assessment $\quad 58$

Due Process $\quad 59$

Reasonable Modifications Will Mitigate the Risk 59

$\begin{array}{ll}\text { Virginia Law } & 60\end{array}$

Change to Direct Threat Provision 63

Spring Arbor University $\quad 64$

State University of New York at Purchase 66

$\begin{array}{ll}\text { St. Joseph's College } & 67\end{array}$

Western Michigan University 69

Finding the Right Balance $\quad 70$

VI. COLLEGE/UNIVERSITY POLICIES AND PRACTICES 72

Applying the Social Ecological Model 73

$\begin{array}{ll}\text { Intrapersonal } & 74\end{array}$

$\begin{array}{ll}\text { Curriculum Infusion } & 77\end{array}$

$\begin{array}{ll}\text { Interpersonal } & 78\end{array}$

Institutional $\quad 81$

Community $\quad 85$

Public Policy $\quad 86$

$\begin{array}{ll}\text { Garrett Lee Smith Memorial Act } & 87\end{array}$

Policy in Response to Campus Shooting Incidents 88

Parental Notification Legislation $\quad 89$

Multiple Levels of Influence: Campus Intervention Teams 90

What Do We Call the Team?

Team Mission $\quad 91$

Team Membership $\quad 92$

Initial and Follow-Up Assessment $\quad 94$

Interventions $\quad 94$

Interaction with Campus Community 95

Risk Management 96

"Minding the Gap" 96

Reframing Mental Health on Campus 97 
VII. TELLING THE STORY

Current Jurisprudence Regarding College/University Liability When a Student is a Threat to Self Synergy Between the Courts and Changes to Title II Implications for Institutional Policies and Practices 


\section{TABLES}

Table Page

2.1. AISP Model Categories 9

3.1. Types of Policy Analysis 27

3.2. Legal Science Typology 32

3.3. Methodology 35 


\section{CHAPTER I}

\section{REASEARCH PROBLEM AND ITS BACKGROUND \\ The Perfect Storm}

A perfect storm may be defined as "a particularly bad or critical state of affairs, arising from a number of negative and unpredictable factors" (Oxforddictionaries.com, 2014, n.p.) This could describe the current state of mental health concerns on college campuses. With advances in treatment, many more students with mental health issues are able to attend college than in the past (Dunkle, 2009; Massie, 2010; Meunier \& Wolf, 2006; Watkins, Hunt, \& Eisenberg, 2011). Surveys conducted by the American College Health Association and Directors of Counseling Centers show that increasing numbers of college students are reporting symptoms of depression and other severe psychological issues as well as taking psychotropic medications (Castillo \& Schwartz, 2013; MacKean, 2011). The campus environment can also be stressful for many students. "Approximately 1,100 college students between the ages of 18 and 24 commit suicide, and nearly 24,000 attempt it" (Rodriguez \& Huertas, 2013, p. 53). Add to the mix that mental health conditions such as bi-polar disorders begin in the age range associated with traditional college students (Massie, 2008; Meunier \& Wolf, 2006).

Rather than proactive planning and care, institutional policies addressing student mental health concerns have been based in fear and a desire for these students to go away 
(Appelbaum, 2006; Massie, 2008; Pavela, 2006 \& 2010). “The incidence of such policies...may be linked to administrators' fears of adverse publicity and legal liability if students commit suicide on campus" (Appelbaum, 2006, p. 914). Schieszler v FerrumCollege 236 F. Supp. 2d 602, 609 (2002) and Shin v Massachusetts Institute of Technology No. 020403, 2005 WL 1869101 (2005) alarmed higher education with findings that a special relationship existed between the institution and the students who committed suicide (Appelbaum, 2006; Lapp, 2010; Pavela, 2006 \& 2010). Although later court rulings have signaled that Schieszler and Shin are exceptions, administrators are still nervous regarding institutional liability (Lapp, 2010; Pavela, 2010).

\section{Research Problem}

"The law does not specifically mandate what a responsible campus must look like, so administrators must integrate good student affairs practice with general legal guidance" (Lake 2011, p. 160). Rather than being proactive and supportive, institutional policies addressing student mental health concerns have been based in fear that the institution will be held liable and viewed negatively. This is the basis for wanting students who are a threat to self to be removed from campus (Appelbaum, 2006; Massie, 2008; Pavela, 2006 \& 2010). This dissertation seeks to understand the relationship between the law and institutional practices regarding college students who demonstrate a threat to self.

\section{Research Questions}

Specifically the research questions are:

1. What is the current jurisprudence regarding the liability of institutions of higher education when the student is considered a threat to self? 
2. Is there synergy between the courts and changes to Title II regulations by the Department of Justice and enforcement of these regulations by the Office of Civil Rights?

3. Taking into consideration the current jurisprudence and the synergy between the courts and changes to Title II regulations, what are the implications for institutional policies and practices when the student is considered a threat to self?

\section{Definitions}

Direct Threat Provision: $\S 35.139$ of Title II of the Americans with Disability Act (ADA) which was amended in 2010 by the Department of Justice so that direct threat may only be defined as a threat to others (Lannon \& Sanghavi, 2011; Lewis, Schuster \& Sokolow, 2012). Under this provision students who are a direct threat may be removed from campus without violating the ADA (Lannon \& Sanghavi, 2011 \& Lewis, Schuster \& Sokolow, 2012).

Disturbing Student: a student who frequently engages in behavior that is disruptive to the learning environment and/or threatening to self/others (Jablonski et al., 2008; Van Brunt \& Lewis, 2014).

Threat to Self: behavior that indicates a student is or at risk of harming him/herself. Title II of the Americans with Disabilities Act, Pub. L. 101-336: prohibits discrimination by public entities, including the services, programs, or activities of all State and local governments and federally assisted programs. It defines discrimination, disability and qualified individual with a disability. Establishes a process for investigating and resolving discrimination complaints (ADA, 1991; Lannon \& Sanghavi, 2011; Lewis, Schuster \& Sokolow, 2012). 


\section{Limitations}

In policy analysis, defining the policy problem provides direction and structure for research and analysis (Bardach, 2012; Dunn, 1981). A potential source of error in policy analysis is examining the wrong problem (Bardach, 2012; Dunn, 1981). This error occurs because most policy analysis examines ill-structured problems, meaning problems that contain competing goals, strategic and operational issues and involve many decision makers (Dunn, 1981).

Ill-structured problems demand that analyst first take an active part in defining the nature of the problem itself. In actively defining the nature of the problem, analysts must not only impose part of themselves on the problematic situation but must also exercise creative judgment and insight. (Dunn, 1981, p. 106) Harris (1973) describes the analyst as being "an advocate—while still being objective" (p. 396). Meaning that a policy analyst is persistent in explaining why there is a problem, why a change is necessary and presents the facts when discussing solutions (Harris, 1973).

In constructing the policy problem for this dissertation, there are two additional limitations. The first is although non-traditional students are growing in numbers (Renn \& Reason, 2012), this dissertation is focused on the development and mental health of the traditional college student aged $18-24$ years. The second is this dissertation is attentive to the policies and practices of four-year colleges and universities. 


\section{CHAPTER II}

\section{REVIEW OF LITERATURE}

\section{Student Behavior: A Historical Concern}

"Unusual or challenging behavior may be indicative of a learning opportunity in waiting, or it could be a sign of an underlying mental health issue" (Jablonski et al., 2008, p. 13). When the behavior moves from once in awhile to all the time or the disruptive behavior escalates and infringes on the ability of other students to learn, there is a disturbing student present (Jablonski et al., 2008; Van Brunt \& Lewis, 2014). Although recent concern about student behavior has been associated with tragic events, student behavior has been an issue since the early days of American higher education (Rudolph, 1990; Stoner \& Lowery, 2004; Waryold, 2013). This concern is reflected in Thomas Jefferson's words to the president of South Carolina College:

The article of discipline is the most difficult in American education. Premature ideas of independence too little repressed by parents, beget a spirit of insubordination which is a great obstacle to science with us and a principal cause of its decay since the revolution. I look to it with dismay in our institution, as a breaker ahead, which I am confident we shall be able to weather. (Patterson, 1984, p. 1465)

The early colleges had strict rules and involved students in studies from sun up to sun down (Rudolph, 1990; Lowery, 1998). Live-in tutors and faculty were responsible for 
making sure that students followed the rules and severe punishment would follow any violation (Lowery, 1998; Rudolph, 1990; Waryold \& Lancaster, 2008). Jefferson writes about the design of his academic village as "every professor would be the police officer of students adjacent to his own lodge" (Patterson, 1984, p. 1223). Strict discipline was a hallmark of the doctrine of in loco parentis (Lowery, 1998). College presidents and faculty felt that this strict control of behavior was necessary to oversee the wellbeing of the students in their custody (Lowery, 1998). This regimented student life is the reason cited for the riots that permeated campuses in the 1800's (Rudolph, 1990). "The rebellions documented the failures of the colleges to provide... satisfactory outlets for quite normal animal energy and human imagination” (Rudolph, 1990, p. 98). Faculty were sometimes harmed in these riots and it should come as no surprise that responsibility for student conduct was a responsibility they were quite willing to give up (Lowery, 1998; Rudolph, 1990; Waryold \& Lancaster, 2008).

The first student personnel staff, the early term for student affairs, was hired in the 1870's to oversee student life and conduct (Waryold \& Lancaster, 2008). These deans of men and deans of women would begin to advocate for viewing students holistically as well as for services and facilities to aid in student development.

The college should make provision for the counseling [sic] of students on educational, personal and vocational matters...The college must assume its share of responsibility for the physical health of the students... The college must assume its share of responsibility for the mental health of its students... and must maintain a mental hygiene service as part of, or parallel to, its physical health service. (Clothier, 1931, p. 13-14) 
In 1949, Blaesser writes about the future of the student personnel profession and discusses six assumptions that structure the profession:

1. That individuals will inevitably have problems in adjusting to a complex society.

2. That personality must be considered as a whole.

3. That there must be an emphasis on prevention.

4. That personality and environment are interrelated.

5. That the individual has the capacity to take major responsibility for his learning and for the solution of his problems.

6. That a common purpose must be defined and must operate in an interdependent democratic society. (p. 144)

Although these assumptions could just as easily have been written today, Blaesser (1949) was writing at a time when institutions were growing by leaps and bounds in response to the GI Bill and campuses were now home to mix of students, some traditional aged, some older and others married and starting families. He calls for better admissions policies to determine fit for college rather than have the student be hurt educationally (Blaesser, 1949). Again this is something that is discussed in the media today when disturbing students make headlines.

Also in 1949, The American Council on Education (ACE) released a revised edition of The Student Personnel Point of View. The revision listed the necessary student personnel functional areas for a college/university (Paterson \& Gregory, 2013). Included in the report was "the treatment of discipline as an educational function designed to modify personal behavior patterns and to substitute socially acceptable attitudes for those 
which have precipitated unacceptable behavior" (ACE, 1949, p. 133). This serves as a reminder that the student affairs profession has its roots in student discipline; which should be thought of as an educational function not simply as punishment or the handing out of sanctions (ACE, 1949).

Mandatory and voluntary leave policies for students with mental health issues or other behavior deemed disturbing are an issue currently under debate. The idea of student leaves of absence can be traced to the early 1960's:

Harvard and other universities to follow came to the adaptive policy of permitting students to take a leave of absence when and as required to "find themselves" before forfeiting the precious opportunity for education. Indeed we are all cognizant of the hordes of students arriving on our campuses with no clear idea of their reason for being there, who they are or what they wish to become, and lacking in varying degrees, the readiness for college. (Kirk, 1962, pp. 231-232) This was a time period that would witness the demise of in loco parentis, student demonstrations and social change. However some of the same sentiments that Kirk expressed of the 1960's students, many faculty and staff express these same feelings about the millennial generation today.

In a paper published in 1968, Philip Tripp predicts what student development will be like in the year 2000. There is one prediction worth noting.

We have yet to deal with the area of teaching people generally to understand their feelings. Our society has been disposed against people admitting they have any feelings. Here is a zone where we must be pioneers and the precursors and the showers of the way. (Tripp, 1968, p. 283). 
Recognizing the student in distress and linking him/her to services is a timeless concern for colleges/universities.

\section{Identifying Disturbing Students}

In the late 1980s Ursula Delworth introduced the AISP Model: AssessmentIntervention of Student Problems to assist with the identification of disturbing students (Dunkle, Silverstein, \& Warner, 2008; Delworth, 2009; Dunkle, 2009; Jablonski et al., 2008). The components of the AISP model include developing a campus intervention team, initial assessment for students of concern and determining appropriate intervention (Dunkle et al., 2008; Delworth, 2009). Delworth (2009) started from the belief that all campuses should have a coordinated system in place for assessing and coordinating information and interventions for students of concern. "Delworth conceptualized her AISP model much more broadly and viewed it as a tool to be used by staff al all levels to quickly assess students and channel them into appropriate on-and-off-campus services for more extensive assessment and intervention" (Dunkle 2009, p. 6). The model proposes three categories that student behaviors can placed in, disturbing, disturbed and disturbing, and disturbed. The characteristics of each category are described in table 2.1.

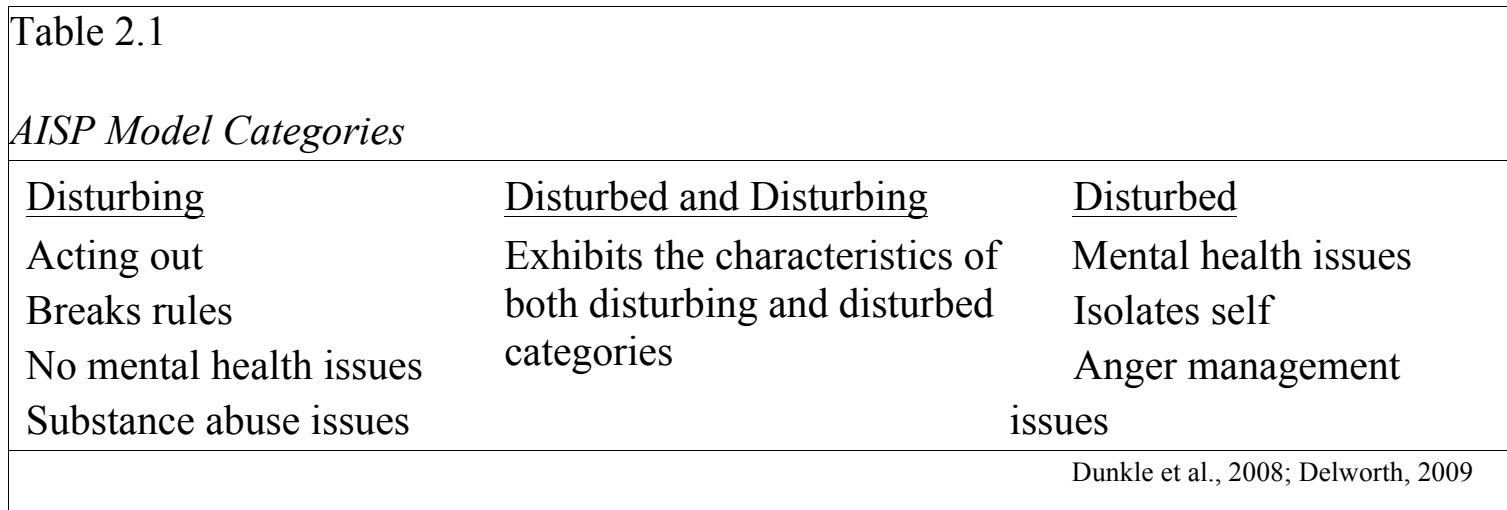


The disturbing student is disruptive and is usually encountered through the student discipline/judicial system (Dunkle et al., 2008; Delworth, 2009). The disturbed student may be the quiet student on campus. He/she has a mental health issue, may or may not be in treatment, but does not usually violate the code of student conduct (Dunkle et al., 2008; Delworth, 2009). The disturbed and disturbing student is both disruptive to the campus community and has a mental health issue (Dunkle et al., 2008; Delworth, 2009). According to Delworth (2009) accurate assessment is dependent upon the information gathered. This may be done through interviews of faculty members, students and staff who have observed the student of concern (Delworth, 2009). Another strategy is to hold a meeting with all the relevant parties around the table to discuss the student and the behavior (Delworth, 2009). "The key question...is whether the student poses an imminent danger to self or others" (Dunkle et al, 2008, p. 596).

To better understand this model consider the following scenarios:

Amy is from a small rural town and chose to attend Large Urban University for a different experience. However one month into the fall semester Amy experiences panic attacks going to her Tuesday/Thursday classes that are located on the farthest part of campus from her residence hall. She also feels overwhelmed in crowded areas and has declined offers to attend football games and tailgating activities. According to the AISP model Amy would be considered a disturbed student. She is isolating herself and the panic attacks would be indicative of anxiety issues that should be evaluated by health/mental health professionals (Delworth, 2009; Van Brunt \& Lewis, 2014).

Blake is 22 years old and starting his first year at college. He is the first one in the classroom and sits in the back of the room, up against the wall. Although he is attentive 
in class, his attention will divert to the hallway when the classroom door is open. Blake expresses a low tolerance for other student's questions and will make comments about students needing to grow up or get with it. A student in class asks him a question about his military service, Blake responds with expletives and storms out of the room. The disturbed and disturbing classification would cover Blake's acting out, anger issues, etc. (Delworth, 2009; Van Brunt \& Lewis, 2014).

After receiving information about Amy and Blake's observed behavior, the campus intervention team can undertake the initial assessment and categorization of the student. The process will then move to intervention. Sometimes it is only necessary to keep the student "on the radar screen." Monitor the student to determine if behavior causes additional concern or ramps up in severity (Dunkle et al., 2008; Delworth, 2009). Other times the student may be referred to departments on campus such as the counseling center, judicial programs, substance abuse programs, academic assistance programs, etc. for additional assessment and intervention (Dunkle et al., 2008; Delworth, 2009). Referrals would be appropriate for both Amy and Blake.

AISP offers a framework for developing campus intervention teams, assessing students and appropriate interventions (Dunkle et al., 2008; Delworth, 2009). In addition, the model is applicable at a variety of higher education institutions and with diverse student populations (Barr, 2009; Dunkle et al., 2008; Dunkle, 2009; McClellan, EklundLeen, Gatti \& Kindle, 2009; Sandeen, 2009; Shang \& Barkis, 2009). It also provides a frame of reference for discussing a variety of student behaviors and how they could be categorized on a continuum. The simplicity and utility encourages communication among professionals on campus and serves to prevent isolation of information (Sandeen, 2009). 
This frame of reference is particularly important as college/universities recognize how today's students will differ from past generations in regards to behavior and the support needed to persist to graduation.

\section{Millennial Students and Mental Health}

The millennial students are different from prior generations in regards to mental health issues. With advances in treatment, many more students with mental health issues are able to attend college than in the past (Dunkle, 2009; Watkins et al., 2011). Current traditional aged college students are also likely to drink more and take more pills than prior generations (Watkins et al., 2011).

Today's students have grown up in a culture in which medication use for psychological troubles is common...Some students may now see medication as a quick fix and easier alternative to counseling. Use of medication is more socially acceptable than in the past, and students may be less inclined to hide their use of medication from their peers. Indeed the use of medication may seem almost trendy in today's world. (Sharkin, 2006, p. 7)

Surveys conducted by the American College Health Association and Directors of Counseling Centers show that increasing numbers of college students are reporting symptoms of depression and other severe psychological issues as well as taking psychotropic medications (Castillo \& Schwartz, 2013; MacKean, 2011). These surveys also support the claim that half to two thirds of the students who report symptoms of depression and other mental health issues will not seek care on campus (Castillo \& Schwartz, 2013; MacKean, 2011). "Our education system is premised on the belief that 
students are willing to abide by the rules we establish and that they will seek help when they need it" (Roy, 2010, p. 8).

Shootings and other violent events on college campuses result in an increased focus on student mental health issues and disturbing behaviors from administrators, faculty, staff, legislators and the general public (Watkins et al., 2011). One side effect of the increased awareness has been that students with mental health issues are all treated as potentially violent students and are frequently subjected to the student discipline system instead of receiving support and care (Bazelon Center for Mental Health Policy and the Law, 2007; Center for Mental Health Services, Substance Abuse and Mental Health Services Administration, 2007; Salzer, 2012; Stuart, 2012; Watkins et al., 2011). Consider the case of Nott v. The George Washington University No. 05-8503 Superior Court of the District of Columbia (2005). George Washington University (GWU) student Jordan Nott sought help at the GWU Hospital because he was experiencing depression and reaction to a medication he was taking after witnessing a friend commit suicide. While in the hospital, Nott was informed by a representative from GWU that he was unable to return to living in the residence hall and was under interim suspension for violating the conduct code for "being a danger to himself and others" (Nott, 2005). Nott could voluntarily withdraw or face a disciplinary hearing that could result in expulsion (Nott, 2005). Nott voluntarily withdrew with the hope of returning once he was medically cleared. Unfortunately GWU did not clear Nott to return as a student and barred him from campus, a decision that resulted in a lawsuit that was settled out of court (Nott, 2005). Nott wrote GWU about his experience: 
If I had known how I would be treated, I never would have checked myself into that hospital. In fact, your charges and the behavior of your institution prevented me from focusing on my condition. Rather your actions threw on me a huge feeling of failure which, needless to say, pushed me further into depression...I can guarantee you that you did me no favor by removing me from my closest friends and sending me home...I can guarantee you that you will do no future student a favor by doing the same to him or her. (Nott, 2005, line 76)

Unfortunately the experience of Jordan Nott has been repeated on campuses across the country (Lapp, 2010; Stuart, 2012).

"Emerging adulthood brings with it a greater likelihood of mental illness as a function of maturation between adolescence and adulthood" (Stuart, 2012, p. 324). Given that the college years are a time when psychiatric conditions such as bipolar disorders, schizophrenia begin to appear (Hollingsworth, Dunkle \& Douce, 2009; Stuart, 2012; Van Brunt \& Lewis, 2014), students need to be able to access treatment and support services. It must be remembered that the vast majority of students with a mental health concern will be successful in college and never cause a disruption (Hollingsworth et al., 2009; Stuart, 2012; Van Brunt \& Lewis, 2014). However for those that do need services and support, institutions must be cognizant that policies do not result in added barriers or consequences that cause students to abandon the help they need.

\section{Gender and Mental Health}

Although the millennial generation has grown up accustom to therapy and medication, they still face pressure to conform to societal expectations of behavior associated with gender (Sharkin, 2006). Although some use gender and sex 
interchangeably, sex is biologically being male or female (Ali, Caplan \& Fagnant, 2010). Gender incorporates all the societal norms associated with femininity and/or masculinity (Ali, Caplan \& Fagnant, 2010). "The dominant societal form of femininity-emphasized femininity-stresses personal traits of submissiveness, nurturance, and emotional sensitivity as ideals. In contrast, dominant conceptions of masculinity-termed hegemonic masculinity-associates men with assertiveness, competitiveness and independence" (Rosenfield \& Mouzon, 2013, p. 280).

The behavioral expectations associated with gender have an influence on physical and mental health. Although both genders are exposed to violence, men are more likely to experience physical assaults such as fighting and gun violence (Ludeman, 2004; Rosenfield \& Mouzon, 2013). A study of college males in California found that "one in seven had been in a physical fight in the past year" (Courtenay, 2011, p. 200). Family, peers and the media author and support the message that violence is an acceptable way to solve a conflict (Kimmel, 2013). Also one in ten college men regularly carry a gun, knife or other weapon (Courtenay, 2011). The access to a lethal weapon may account for males using a firearm most often as a means for suicide (Lake, 2008). Other behaviors associated with college student conformity to hegemonic masculinity include heavy drinking, seeming not to care about academics, using women and being highly competitive (Harper, Harris \& Mmeje, 2005; Harris, 2010; Harris \& Edwards, 2010; Harris \& Struve 2009; Laker, 2009; Lindo et al., 2011). These performances account for the reason one is likely to observe higher numbers of college men in the disturbing and disturbed \& disturbing categories as identified by the AISP model, as well as frequent encounters with the student judicial system (Harper et al., 2005; Harris and Struve 2009; 
Laker, 2003 \& 2009).

Gender stereotypes also influence physical and mental health through body image concerns (Ali, et al., 2010; Parent \& Moradi, 2011; Rosenfield \& Mouzon, 2013).

Exposure to messages through media and other societal communication affect definitions of beauty and the ideal body (Parent \& Moradi, 2011). The quest for the unattainable body can lead to eating disorders and abuse of drugs such as anabolic steroids, amphetamines and other unsafe practices that males use to bulk up and females to slim down (Parent \& Moradi, 2011). On college campuses, increasing numbers of college men are being treated for body image disorders (Parent \& Moradi, 2011). This trend is important for campus counseling and fitness centers to take note of since outreach on this topic has typically been aimed at college females (Parent \& Moradi, 2011).

The ability to ask for help is also influenced by gender. It is consistent with societal norms for women to discuss emotions and to ask for assistance (Ali, et al., 2010; Bronson, Drum, Smith \& Burton Denmark, 2014; Rosenfield \& Mouzon, 2013). However, men internalize the need to be their own problem solvers and not expected to show feelings or emotions (Tang, Oliffe, Galdas, Phinney \& Han, 2014; Vogel, Wester, Hammer \& Downing-Matibag, 2013; Yousaf, Popkat \& Hunter, 2015). Given the importance of peer groups to the traditional college-age male (Davis \& Laker, 2004; Harris, 2010; Harris \& Edwards, 2010; Harris \& Struve, 2009; Laker, 2003; Lindo, Swensen \& Waddell, 2011), there is immense pressure to perform to the male norm. According to Vogel et al. (2013) men subscribing to "traditional male gender roles...may discourage men from referring others who may be struggling with mental health concerns [and] may also stigmatize other's emotional sharing with mental health professionals" (p. 
6). Thus a vicious cycle is created of men being reluctant to seek help and not receiving any encouragement from peers to seek help. This underpins the research findings that women are more likely to express suicide ideation and receive help where as men are more likely to complete the act and die (Bronson et al., 2014).

Even when men are able to break this cycle and seek help, there are gender barriers. "Depression is ranked among the top five health impediments to academic performance among college-age men" (Tang et al., 2014, p. 219). Yet clinicians are less likely to diagnose men with depression (Courtenay, 2011). According to Ali et al. (2010) this may be explained in part because "the diagnostic categories are invented, defined and often re-invented...by White American male psychiatrists who are positioned to describe what is normal and what is abnormal" (p. 91). The stereotypes based on hegemonic masculinity are insidious. And it is not just men, women play a huge role in supporting hegemonic masculinity even though they experience the negative outcomes in the form of interpersonal violence and watching the men they care about suffer (Davis \& Kimmel, 2011).

In order to disrupt the norms, the messages need to change (Harris, 2010; Harris \& Edwards, 2010; Harris \& Struve, 2009; Vogel et al., 2013; Yousaf et al.; 2015). "Promote peer support that is consistent with male gender norms, such as emphasizing the strength required to support a friend and reach out for support, rather than associating help-seeking with emotional closeness or vulnerability" (Bronson et al., 2014, p. 290). College/university administrators need to not only understand how student developmental issues play out on campus but also the ramifications of culture and gender to provide a supportive learning environment (Englar-Carlson \& Kislica, 2013). 


\section{Behavior that is a Threat to Self}

Most of the discussion surrounding disturbing student behavior focuses on the disruption or threat to others. Behavior that indicates a student is harming him/herself is also a concern. Self-harm behavior includes eating disorders, nonsuicidal self-injury (NSSI), attempted suicide and suicide.

\section{Eating Disorders}

Prevalence of eating disorders among college students ranges from eight to $17 \%$ (Eisenberg, Nicklett, Roeder \& Kirz, 2011). Males and females differ in behavior related to eating disorders. Females with eating disorders are more likely to engage in higher intensity workouts and binge drink than males with eating disorders (Eisenberg et al., 2011). "For both males and females, eating disorders are associated with depression, anxiety, suicidal ideation and non nonsuicidal self-injury” (Eisenberg et al., 2011, p. 705). College students report that eating disorders and body image concerns do not often provoke them to seek counseling or other treatment for these issues (Nordberg, Hayes, McAleavey, Castongway \& Locke, 2013). Avoiding treatment is also associated with fear of giving up routines that allow the students to cope with anxiety and shame about behavior (Sheehy \& Commerford, 2006). Intervention is important as anorexia has a mortality rate estimated at 20\% (Sheehy \& Commerford, 2006).

\section{Nonsuicidal Self-Injury}

Nonsuicidal self-injury (NSSI) is the deliberate act of harming ones body without suicidal intent (Whitlock et al., 2011). NSSI behavior typically begins at age 16 and continues into the early or mid-20s (Klonsky, 2011). Prevalence estimates for NSSI among the college student population vary from ten to $38 \%$ (Andover, Primack, Gibb \& 
Pepper, 2010). College students that have served in the military are at an increased risk of engaging in self-harm (Blosnich, Kopacz, McCarten \& Bassarte, 2014). Although males and females have similar rates for engaging in NSSI behaviors, the methods vary (Andover et al., 2010; Whitlock et al. 2011). Common methods include cutting, burning, hitting, and preventing cuts from healing (Klonsky, 2011). Females are more likely to engage in cutting, where as males engage in self- hitting (Klonsky 2011). This correlates with males engaging in NSSI behavior as a sign of strength (Andover et al., 2010). Also "males were more likely than females to engage in NSSI during states of anger and while under the influence of drugs and alcohol" (Whitlock et al., 2011, p. 697). Reasons given for engaging in the behavior include releasing stress, wanting to feel something and getting attention (Klonsky, 2011). Use of self-injury as a coping mechanism may be one reason why just over $20 \%$ of students engaged in NSSI seek help (Nordberg et al., 2013).

\section{College Student Suicide}

Suicide is the second leading cause of death for traditional age college students (Massie, 2010; McNicholl, 2014). One in ten college students have created a suicide plan (McNicholl, 2014). An average of 1,100 college student deaths are attributed to suicide and 24,000 students attempt it each year (Massie, 2010; McNicholl, 2014; Rodriguez \& Huertas, 2013). Approximately $80 \%$ of college students who commit suicide never engaged in campus counseling services (McNicholl 2014). There are gender differences in the means used to commit suicide with males using a firearm most often (Lake, 2008). Although these statistics are very troubling to those working in higher education, suicide rates for college students are half the rate of peers not enrolled in postsecondary education (Gray, 2007). The difference may be due to decreased access to lethal 
weapons; engagement with peers, activities, classes, and faculty/staff; and access to medical and psychological services (Pavela, 2006).

\section{Addressing Student Well-Being}

According to the American Council on Education:

Mental and behavioral health is a critical component of well-being for all students, and having a campus culture and learning environment that supports healthy minds is a core need deeply centered in the mission of every institution of higher education. (Douce \& Keeling, 2014, p. 3)

Mental and behavioral health is a strategic issue and a challenge that must be addressed through culture and policy changes to ensure an environment that is respectful, engaging and conducive to learning (Roy, 2010). The relationship between colleges/universities has changed over time. A preventative law system brings together legal counsel administrators and faculty to cooperatively review existing policy in light of the current legal and regulatory environment and implement needed policy revisions and training for campus stakeholders (Lugg, 2012). The outcome is that faculty, staff and students will understand why a policy exists and how its implementation will support the mission and values of the institution (Lugg, 2012). This practice recognizes that creating a campus culture that supports student well-being and learning requires understanding the intersection of law, policy and student development (Lugg, 2012).

\section{Institutional Duty}

Often college/university policy regarding student behavior that is a threat to self or others is based on reducing institutional risk or negligence (Appelbaum, 2006; Massie, 2008; Pavela, $2006 \& 2010$ ). For a negligence case to proceed in the courts, the plaintiff 
needs to prove that he/she is owed a duty by the defendant; that the duty was breached; that there is an injury/damage; that the breach of duty was the cause and that the damage was foreseeable (Lake, 2011 \& 2013; Sokolow, Lewis, Keller \& Daly, 2008). A duty may be defined as a responsibility (Lake, $2011 \& 2013)$. If there is not a duty/responsibility owed to the plaintiff the case does not go forward (Lake 2011 \& 2013; Sokolow et al., 2008). A post secondary institution may assume a duty through "(i) the special relationship theory; (ii) duties owed by a college or university based on its status as a landowner; and (iii) duties owed by campus police who undertake to render services for the protection of students" (Sokolow et al., 2008, p. 320). Institutions have several defenses in negligence cases. If the institution is public, qualified immunity may be used as long as the defendants named were acting within the scope of their job duties (Blanchard, 2013). Institutions may also claim that the student knew the risk when he/she acted (Blanchard, 2013). Injury from underage drinking would be an example, as the student knows he/she is engaging in an illegal activity that has the potential for self-harm and therefor assumed the risk. (Blanchard, 2013).

The courts have taken differing views through out history of the duty that is owed to students by a college/university (Lake, $2011 \&$ 2013; Sokolow et al., 2008). From the beginning of higher education in the United States to the late 1950's/early 1960's the courts treated institutions of higher education with deference (Griffin, 2009; Lake, 2011 $\&$ 2013). This time period is referred to as the era of in loco parentis (Griffin 2009; Lake, $2011 \& 2013)$. According to the courts, postsecondary institutions held a parental relationship to their students and could implement rules and regulations that were not to be questioned by the students or outsiders (Griffin, 2009; Lake, 2011 \& 2013). A 1913 
legal case, Gott v Berea College describes colleges as acting as the parent (Blanchard, 2013). Although most contend that in loco parentis meant colleges/universities had a duty to protect students because they assumed a custodial relationship with the students (Blanchard, 2013; Sokolow et al., 2008), Lake asserts that "in higher education law, the doctrine of in loco parentis never created a responsibility; it was merely a form of immunity" (Lake, 2008, FN65). Lakes contention of immunity would support the court's treatment of higher education institutions.

The late 1950s, '60s and early '70s were about social change and protest in the United States (Bickel \& Lake, 1999). Through court cases such as Dixon v Alabama State Board of Education 294 F.2d 150 (1961) and Esteban v. Central Missouri State College 277 F.Supp. 649 (1967), it was also the time period that witnessed due process coming to campus. Dixon and Esteban lay out the expectations that students receive adequate advance notice of the hearing, the student codes that were violated and the evidence (Dixon, 1961; Esteban, 1967; Lowery, 2008). Due process also includes the ability of the student to present his/her own side, a bias free hearing board, and the ability to ask questions of the witnesses presented by the complainant as well as present his/her own witnesses (Dixon, 1961; Esteban, 1967; Lowery, 2008). "The intervention of courts into university life signaled an end to university immunity and a shift in higher education law" (Bickel \& Lake, 1999, p. 36). It is interesting to note that this era is often cited as the time when formalizing or "creeping legalism" of student conduct programs began (Lowrey, 2008). However the court in Esteban warns against student conduct systems becoming similar to criminal processes (Esteban, 1967; Lowery, 2008). 
The bystander era is a time period where the courts viewed students as adults who were responsible for their own actions (Griffin, 2009; Lake, 2011 \& 2013). In Bradshaw v. Rawlings 612 F.2d 135 (1979), the U.S. Court of Appeals Third Circuit declares in loco parentis over but in exchange for rights and autonomy students sacrifice protection (Bradshaw, 1979; Sokolow et al., 2008). In this era college/universities just stood by, hence the term bystander, as students were injured by their actions and the behavior of other students (Lake, $2011 \&$ 2013). From this bystander era we have Eisman $v$ State of New York, 70 N.Y.2d 175, 511 N.E.2d 1128, 518 N.Y.S.2d 608 (1987) where a negligence suit was filed after a ex-convict, who was enrolled in a higher education program for offenders, murdered two students. The Court of Appeals of New York overturned a ruling that there was a duty to the students to screen applicants and have a risk management plan for the program. According to the court "the college did not have a heightened duty in admissions, or a duty to restrict the prisoner's activity on campus, for the protection of other students" (Eisman, 1987). The court adds "imposing liability on the College for failing to screen out or detect potential danger signals in Campbell would hold the college to a higher duty than society's experts in making such predictions" (Eisman, 1987). Eisman has direct applicability to the question of whether there is a duty to review criminal histories to meet an obligation to provide a safe campus.

In the 1990's higher education entered a legal climate referred to as the facilitator era (Blanchard, 2013; Lake 2011 \& 2013). Furek v University of Delaware 594 A.2d 506 (1991) signaled the end to the college/university as bystander. In Furek the courts found that the University of Delaware shared responsibility for the injury suffered by Furek in a hazing incident because "where there is direct university involvement in, and knowledge 
of, certain dangerous practices of its students, the university cannot abandon its residual duty of control" (Furek, 1991, line 520). The University of Delaware knew that hazing was occurring, had a policy against it and repeatedly communicated the policy to Greek organizations, but took no action beyond the communication (Blanchard, 2013; Furek, 1991). The court also felt that injury from hazing was foreseeable because of the knowing that hazing occurred and the policy prohibiting it (Furek, 1991).

In addition to contributory negligence, the facilitator era is characterized by applying principles of business law to higher education (Cloud, 2013; Lake 2011 \& 2013). Students are viewed as consumers and the duty owed for safety is equivalent to the relationship between a business owner and customer (Cloud, 2013; Lake, 2011 \& 2013). For example in Nero v. Kansas State University 253 Kan. 567, 861 P.2d 768 (1993) the Supreme Court of Kansas ruled that the university did not have a responsibility to protect students from criminal behaviors of other students (Nero, 1993). However as a landlord, the university had a duty to protect students in the residence halls (Nero, 1993). Thus the many roles of a college/university put it in a complex legal setting. To navigate this legal environment "effective administrators rely on risk management and preventive law to ensure safety and reduce institutional liability in negligence actions. For example, many institutions now require background checks of all potential employees and all student applicants" (Cloud, 2013, p. 469).

Currently higher education is in a transition phase from the facilitator era to the compliance era (Lake, 2013). The compliance era is characterized by falling in line with federal and state mandates including such activities as the investigation and enforcement of student conduct, mandatory reporting, efforts to reduce under age drinking, etc. 
According to the Third Restatement of Torts, $\S 38$ allows the courts to consider statutes as the basis for determining whether an affirmative duty exists (Bublick, 2013). Although, we are in early years of this phase it is possible to speculate that greater regulatory influence will result in courts finding that a duty is owed to students through statute compliance. Another change in the Third Restatement is in $\S 40$ with the addition of schools and students as a special relationship that creates an affirmative duty (Bublick, 2013). There is recognition that schools is broad category "and because of the wide range of students to which it is applicable, what constitutes reasonable care is contextual- the extent and type of supervision required of young elementary-school pupils is substantially different from reasonable care for college students" (Bublick, 2013, p. 194). Even with that caveat, it is possible if the courts accept and act on the Third Restatement that "where the student...exhibits behavior that should put the school on notice of an imminent probability that he or she will harm others, the school may have a special relationship and a duty to prevent harm" (Sokolow et al., 2008, p. 327).

\section{Can Colleges/Universities Do Better?}

When a student is a threat to self "institutions respond to self-destructive behavior with actions that seem more calculated to limit liability than to address the needs of their students" (Colker \& Grossman, 2014, p. 15). In order to create a caring and safe environment for learning higher education professionals need to understand the law and focus on how it allows for care and concern, instead of focusing on what cannot be done. 


\section{CHAPTER III}

\section{METHODOLOGY}

In the literature, policy analysis has been described as a research method used to define a problem, determine what the current policy is (or if there should be one), ascertain if the current policy is working as intended, and determine if there are other approaches to address the problem (Bardach, 2012; Dunn, 1981; Harris, 1973; O'Connor, 2011). Dunn (1981) describes it as "an applied social science discipline which uses multiple methods of inquiry and argument” (p. 35). First, Vines Elue \& Pindar (2015) note that a "policy studies approach to researching legal topics is the broadest and most loosely defined" of the existing methodologies (p. 128).

A policy analysis can take three forms. Prospective policy analysis is done in advance of implementing a policy. Prospective analysis is concerned with defining a problem and predicting what policy solution will provide the desired outcome (Dunn, 1981). Retrospective policy analysis seeks to answer the question: What changes resulted from the implementation of a policy? This type of analysis examines why a particular policy was chosen, the benefits and consequences and if the desired outcomes were achieved (Dunn, 1981). Integrated policy analysis combines prospective and retrospective to "provide for the continuous monitoring and evaluation policies over time" (Dunn, 1981, p. 54). Table 3.1 provides a comparison of the three types of analysis 


\begin{tabular}{|c|c|c|}
\hline \multicolumn{3}{|l|}{$\begin{array}{l}\text { Table } 3.1 \\
\text { Types of Policy Analysis }\end{array}$} \\
\hline Prospective & Retrospective & Integrated \\
\hline $\begin{array}{l}\text { Defines the problem and } \\
\text { proposes solutions to } \\
\text { achieve outcomes }\end{array}$ & $\begin{array}{l}\text { Describes the problem and } \\
\text { the criteria that lead to } \\
\text { policy selection }\end{array}$ & $\begin{array}{l}\text { Defines/describes the } \\
\text { problem and the policies } \\
\text { that have been } \\
\text { implemented over time }\end{array}$ \\
\hline Future oriented & Past oriented & $\begin{array}{l}\text { Learns from the past to } \\
\text { predict the future }\end{array}$ \\
\hline $\begin{array}{l}\text { Focuses on forecasting } \\
\text { and recommendations }\end{array}$ & $\begin{array}{l}\text { Focuses on understanding } \\
\text { the problem and the } \\
\text { benefits/consequences of } \\
\text { the implemented policy }\end{array}$ & $\begin{array}{l}\text { Examines both theory and } \\
\text { practice to understand } \\
\text { unresolved issues }\end{array}$ \\
\hline
\end{tabular}

Policy is dynamic and there may a cascade effect of one policy decision leading to others (First et al., 2015). Integrated policy analysis allows for this interdependence of decisions and outcomes (Dunn, 1981). This dissertation will use integrated policy analysis to:

- Define the policy problem regarding college students who are a threat to self.

- Analyze the current legal opinion of the courts regarding institutional liability when college students are a threat to self (Chapter IV).

- Examine the benefits and consequences to date of the 2010 Department of Justice change to the direct threat provision in Title II legislation (Chapter V). This change modified $\S 35.139$ so that direct threat means only a significant threat to others. The old language read significant threat to self or others (Lewis et al., 2012). 
- Determine the implications for institutional policies and practices when the student is considered a threat to self (Chapter VI).

Bardach (2012) defines eight steps to follow for policy analysis:

1. Define the problem

2. Assemble some evidence

3. Construct the alternatives

4. Select the criteria

5. Project the outcomes

6. Confront the trade-offs

7. Decide

8. Tell the story (p. xvi)

Steps six through eight can be condensed to communicating the results. These steps will serve as a methodological plan for this dissertation

\section{Define the Problem}

In policy analysis, defining the policy problem provides direction and structure for research and analysis (Bardach, 2012; Dunn, 1981). The characteristics of policy problem as being a component of larger systems, subjective and socially constructed and dynamic also make the definition problematic (Bardach, 2012; Dunn, 1981). In fact a potential source of error in policy analysis is examining the wrong problem (Bardach, 2012; Dunn, 1981). This error occurs because most policy analysis examines illstructured problems, meaning problems that contain competing goals, strategic and operational issues and involve many decision makers (Dunn, 1981).

For this analysis the policy problem has been defined as rather than being proactive and supportive, institutional policies addressing student mental health concerns 
have been based in fear that the institution will be held liable and viewed negatively. This is the basis for wanting students who are a threat to self removed from campus (Appelbaum, 2006; Massie, 2008; Pavela, 2006 \& 2010).

\section{Assemble the Evidence}

This dissertation seeks to understand the relationship between the law and institutional practices regarding college students who demonstrate a threat to self. According to Russo (2015) "systematic inquiry in the law can be described as a form of historical-legal research that is neither qualitative or quantitative" (p. 6). Legal issues occur from uncertainty about how court decisions apply to a set of circumstances (Dernbach, Singleton, Wharton, Ruhtenberg \& Wasson, 2010). Legal scholars are conflicted over duty in student suicide cases. Some feel that the courts should find that colleges/universities have a duty to prevent student suicide; that finding a duty will ultimately make campuses safer because institutions will be forced by the courts to improve mental health services and outreach to students needing help (Lake, 2008; Lapp, 2010; Massie, 2008). Others feel that imposing a duty results in stigma and fear, not safety and care (Lapp, 2010). The following case law, Jain v. State of Iowa, Schieszler v. Ferrum College, Mahoney v. Allegheny College, Shin v. Massachusetts Institute of Technology and Bash v. Clark College will be used to determine what the courts are signaling to institutions of higher education regarding liability when students are a threat to themselves. These are the cases that are discussed in the literature and cited by the courts. There is also the sentiment that Schieszler and Shin scared institutions of higher education with findings that a special relationship existed between the institution and the students who committed suicide (Appelbaum, 2006; Lapp, 2010; Pavela, 2006 \& 2010). 
This dissertation is an integrated policy analysis and therefore is concerned with both pre and post adoption benefits and consequences of the 2010 Department of Justice changes to the direct threat provision in Title II § 35.139. The change redefined direct threat to mean only a significant threat to others. Given the lack of guidance from the Office of Civil Rights (OCR) on how institutions should intervene when students are a threat to themselves (Grasgreen, 2014), campus investigation decision letters authored by OCR and secondary sources, such as law reviews and guidance from professional organizations, will be analyzed to understand why the changes in policy were necessary and how they are being implemented and enforced.

Current institutional practices and policies when students are a threat to self will be identified. The social ecological framework is a useful approach for organizing information for analysis according to the model's five levels of influence (Jed Foundation and Education Development Center (EDC), 2011):

- Individual - strategies that influence the actions of a person

- Interpersonal - strategies to increase peer support

- Institutional - campus policies, climate and culture

- Community - availability of support services

- Public Policy - laws that affect safety, access to services, inter alia.

The social ecological framework recognizes the emotional and physical health of a student is influenced by personal decisions, peer influences, relationships with faculty/staff, campus culture, campus policies as well as local, state and federal policies (DeJong, 2009; DeJong \& Langford, 2002; Jed Foundation \& Education Development Center, 2011; Jodoin \& Robertson, 2013). According to Jodoin \& Robertson (2013) 
utilizing this approach allows for strategic analysis of the problem, identification of existing programs/policies and gap analysis to lead to new policy/program development.

\section{Construct the Alternatives}

This step has been likened to a funnel in terms of starting with many alternatives and narrowing down (Bardach, 2012). The alternatives for this analysis are:

\section{Liability}

a) Institutions do not have a duty to students who self-harm.

b) Institutions do have a duty to protect students from self-harm.

Changes to Title II $\$ 35.139$

a) The changes have not made any difference in the manner institutions treat students who are a threat to self.

b) The changes have improved the manner institutions treat students who are a threat to self.

\section{Current Institutional Practices}

a) There is no relationship between current legal decisions/Title II $\S 35.139$ and current institutional policies/practices regarding college students who demonstrate a threat to self.

b) There will be a relationship between current legal decisions/Title II $\S 35.139$ and current institutional policies/practices regarding college students who demonstrate a threat to self.

\section{Select the Criteria}

When studying a legal issue there are four guiding questions to consider. "(1) How does the law read? (2) How ought the law read? (3) What are the consequences of 
applying a certain legal rule? (4) What is the law?'(Smits, 2012, p. 9). Each of these questions links to a specific approach used to "describe the law, ask how the law works in society, and can deal with theoretical questions about the nature and development of the law" (Smits, 2012, p. 34) Descriptive legal science is concerned with how the law reads (Smits, 2012). This perspective employs a neutral approach to reporting on cases, concerned with the "what is" rather than what ought to be (Smits, 2012). Normative legal science addresses "what individuals, firms, states, and other organizations ought to do or ought to refrain from doing" (Smits, 2012, p. 35). The application and intended/unintended consequences of the law are concerns in the domain of the empirical approach. What is the law? How did it come to be? What societal factors influenced its development? These questions are in the realm of theoretical legal science (Smits, 2012).

\begin{tabular}{llll|}
\hline Table 3.2 & & \\
$\begin{array}{l}\text { Legal Science } \\
\text { Typology }\end{array}$ & Normative & Empirical & Theoretical \\
\hline Descriptive & $\begin{array}{l}\text { How people and/or } \\
\text { organizations } \\
\text { should behave } \\
\text { under the law }\end{array}$ & $\begin{array}{l}\text { What happens, } \\
\text { positive and } \\
\text { negative, when a } \\
\text { law is applied } \\
\text { reads the law }\end{array}$ & $\begin{array}{l}\text { Why is this ruling } \\
\text { needed at this } \\
\text { particular time in } \\
\text { society }\end{array}$ \\
\hline & & &
\end{tabular}

Judicial decisions contain six elements: 1) the facts of the case; 2) definition of the legal issue; 3) the rule of the law under consideration; 4) the holding or how the rule of the law applies to the facts of the case; 5) the ruling of the court; and 6) the reasons for the ruling (Dernbach, et al., 2006). By using the guiding questions, one is able to evaluate a legal case for meaning (Russo, 2006). Knowing what facts and prior court cases lead to 
the decisions of the courts is as important as finding out the intended and unintended outcomes of the decision.

The four guiding questions are also useful for analysis of the change to the direct threat provision in Title II $\S 35.139$. Primary sources consisting of the Title II statute and OCR decision letters, pre and post wording change, can provide facts, rationale and information about intended and unintended consequences (Russon, 2006). The decision letters serve as case studies and allow for the analysis of cultural and social context as well as application of the law (Lugg, 2014).

Once current institutional practices, best practices and model policies have been organized according to level of influence (individual, interpersonal, institutional, community and public policy), assumption analysis will be used to synthesize the information. Identifying the stakeholders, detecting the explicit and implicit assumptions and prioritizing these assumptions based on importance to the stakeholder allows for a deeper understanding of how the policy/practice may provide a solution for the problem (Dunn, 1981).

For example the stakeholders in an involuntary leave policy may be identified as the institution, the student and the parents. Assumptions from the institutional perspective may be reducing risk, not able to ensure safety of student and others, and not having adequate staff/facilities to meet the needs of a student at risk of self-harm. Assumptions from the student may include if I seek help I will lose access to my education and my peers. The parents may also have a similar assumption. Examining the assumptions for validity and importance may lead to the determination that this policy is not the best solution to the problem for the stakeholders involved. 


\section{Project the Outcomes}

This step in the process would be easier if policy analysts were given crystal ball to be able to predict the future. Given this inability, there are some criteria that can aid with predicting outcomes. Reviewing the problem statement can provide information about direction and magnitude of change and interventions (Bardach, 2012).

For this analysis the policy problem has been defined as rather than being proactive and supportive, institutional policies addressing student mental health concerns have been based in fear that the institution will be held liable and viewed negatively. This is the basis for wanting students who are a threat to self removed from campus (Appelbaum, 2006; Massie, 2008; Pavela, 2006 \& 2010). The projected outcomes for this analysis are:

- Institutions of higher education understanding how the courts view institutional duty when a student commits an act of self-harm will result in policies/practices that are designed to help keep students enrolled in the institution.

- Institutions of higher education understanding that the change in the direct threat provision in Title II $\S 35.139$ is aligned with the courts view of institutional duty will result in policies/practices that are designed to help keep students enrolled in the institution.

Table 3.3 provides a summary of the steps of policy analysis as applied to each research question. 


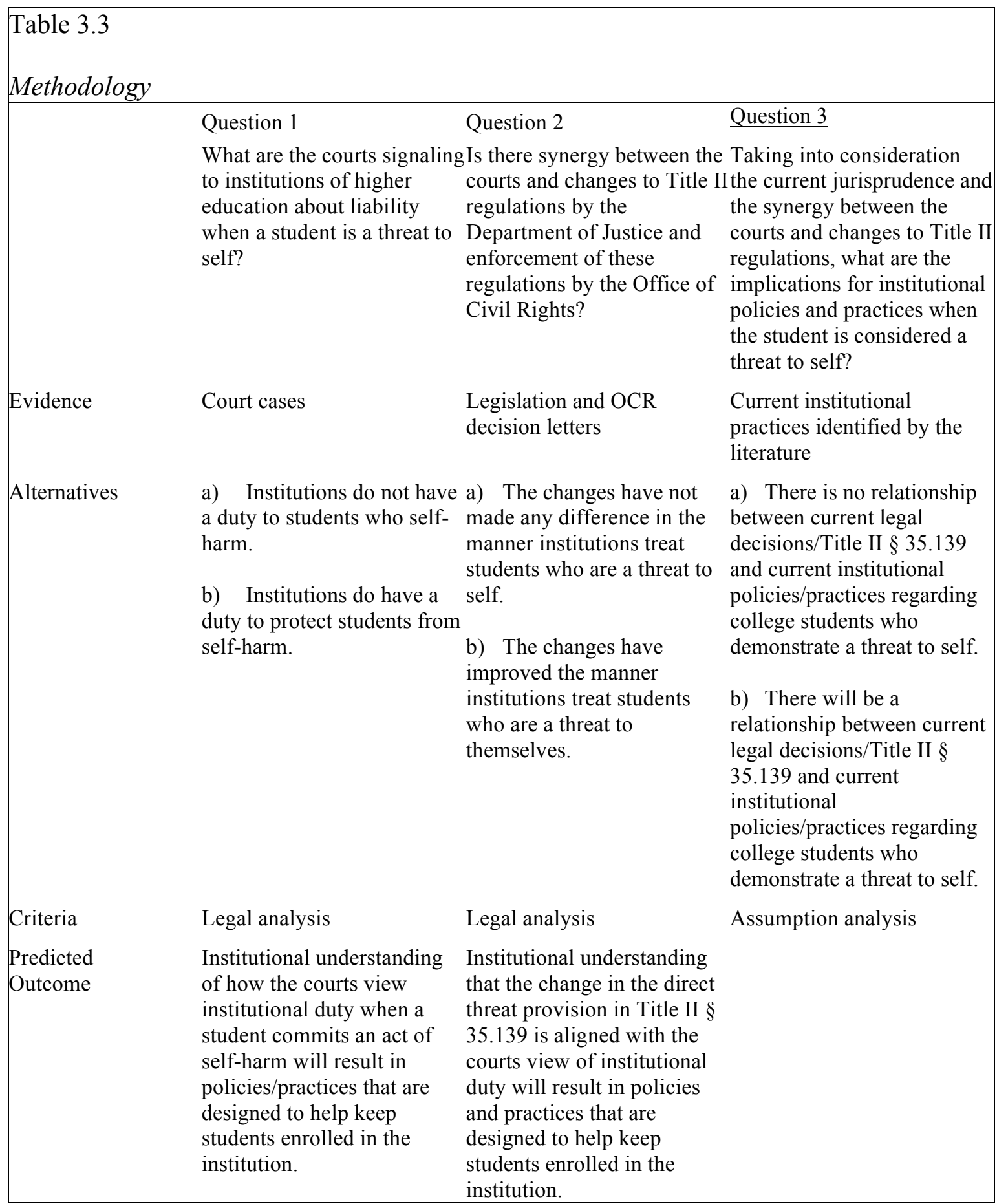

According to O'Connor (2011) “policy analysis is most useful when...there’s

usually some public concern about the morality or goodness of the organization and the analysis is not concerned with disinterested description but recommending something on 
the basis of moral argument" (n.p.). Student learning is of concern to higher education stakeholders. Consider the economic impact alone.

Each four-year college graduate generates, on average, $\$ 5,900$ more per year in state, federal, and local tax revenue than each high school graduate. Over a lifetime, each generates, on average, $\$ 177,000$ more in tax revenue than those with only a high school degree (U.S. Department of Education, 2011, p. 1). Yet if a student displays behavior indicating that he/she is a threat to self, a college/university may decide the student is unfit to stay on campus (Appelbaum, 2006; Lapp, 2010; Pavela, 2006 \& 2010). This decision has individual, communal and economic implications.

Mental and behavioral health is a strategic issue and a challenge that must be addressed through culture and policy changes to ensure an environment that is respectful, engaging and conducive to learning (Roy 2010). Utilizing policy analysis to understand the relationship between the law and institutional practices regarding college students who demonstrate a threat to self is consistent with O'Connor's (2011) recommendation. 


\section{CHAPTER IV}

\section{COLLEGE/UNIVERSITY LIABILITY WHEN}

\section{A STUDENT IS A THREAT TO SELF}

The term tort in Latin means trusted (Alexander \& Alexander, 2011). "Tort actions are brought to compensate individuals for harm caused to them by unreasonable conduct of others" (Alexander \& Alexander, 2011, p. 324). Tort law can be divided into three areas negligence, intentional torts and strict liability (Alexander \& Alexander, 2011; Lake, 2013). An intentional tort results when a person knowingly commits an action that will result in harm; such as assault or battery (Alexander \& Alexander, 2011). Strict liability results from harm caused by an unusual hazard (Alexander \& Alexander, 2011). In higher education settings, strict liability is rare but an example would be injury from a lab experiment (Alexander \& Alexander, 2011). Negligence, or the failing to do what a reasonable person would do, is the most common tort in higher education (Alexander \& Alexander, 2011; Lake, 2013).

For a negligence case to proceed in the courts, the plaintiff needs to prove that he/she is owed a duty by the defendant; that the duty was breached; that there is an injury/damage and that the breach of duty was the cause (Lake, $2011 \& 2013$; Sokolow, Lewis, Keller \& Daly, 2008). A duty may be defined as a responsibility (Lake, 2011 \& 2013). If there is not a duty/responsibility owed to the plaintiff the case does not go forward (Lake 2011 \& 2013; Sokolow et al., 2008). Colleges/universities may assume a 
duty through "(i) the special relationship theory; (ii) duties owed by a college or university based on its status as a landowner; and (iii) duties owed by campus police who undertake to render services for the protection of students" (Sokolow et al., 2008, p. 320). Institutions have several defenses in negligence cases. If the institution is public, qualified immunity may be used as long as the defendants named were acting within the scope of their job duties (Alexander \& Alexander, 2011; Blanchard, 2013). Institutions may also claim that the student knew the risk when he/she acted (Alexander \& Alexander, 2011; Blanchard, 2013; Lake, 2013).

It is an accepted legal principle that there is no duty to help another person unless there is a special relationship. Historically the courts have viewed suicide as a selfimposed act and only recognized liability if defendant actions lead to the suicide or in rare instances there was duty to prevent the suicide (Alexander \& Alexander, 2011; Lake, 2013). This view of suicide as an intervening cause is espoused in Bogust v. Iverson 102 N.W.2d 228 Wis. (1960) which is the first published appellate case dealing with college student suicide (Alexander \& Alexander, 2011; Fossey \& Moore, 2010). Currently, legal scholars are conflicted over colleges/universities duty in student suicide cases. Some feel that the courts should find that colleges/universities have a duty to prevent student suicide. Their argument is finding a duty will ultimately make campuses safer because institutions will be forced by the courts to improve mental health services and outreach to students needing help (Lake, 2008; Lapp, 2010; Massie, 2008). Others counter the duty argument by pointing out that when courts recognized a special relationship, colleges/universities responded with mandatory leave and withdrawal policies (Lapp, 2010). The result was greater stigma not safety and care (Lapp, 2010). 
This chapter will review the following case law, Jain v. State of Iowa 617 N.W.2d 293 (2000), Schieszler v. Ferrum College 236 F. Supp. 2d 602 (2002), Mahoney v. Allegheny College No. 892-2003 Crawford County (2005), Shin v. Massachusetts Institute of Technology No. 020403, 2005 WL 1869101 (2005), and Bash v. Clark College 22 Mass. L. Rep 84; 2006 Mass Super. (2006) to determine what the courts are signaling to institutions of higher education regarding liability when students are a threat to themselves. These cases get at the crux of the debate surrounding institutional duty and students who are a threat to self. Schieszler and Shin support the duty argument with findings that a special relationship existed between the institution and the students who committed suicide (Appelbaum, 2006; Lapp, 2010; Pavela, 2006 \& 2010. Rulings in Mahoney and Bash declined to follow Shin instead finding that there is not a duty (Lapp, 2010).

\section{Jain v. State of Iowa}

Sanjay Jain was in the first semester of his freshman year at the University of Iowa. Although successful academically in high school, he was struggling in a couple of classes and had been placed on probation for breaking residence hall policy (Jain, 2000). Shortly before Thanksgiving break, Sanjay and his girlfriend had an argument in his residence hall room. Sanjay had placed his moped in the room and was planning to use it to commit suicide. The argument resulted because his girlfriend was trying to take the keys to prevent the suicide. Resident Assistants (RAs) on duty responded to the argument and diffused the situation (Jain, 2000). The Complex Director (CD) met with Sanjay the following day. During the conversation he was "evasive and refused to admit or deny that he had tried to commit suicide" (Jain, 2000, p. 295). The CD discussed resources 
available to Sanjay and told him to remove the moped (Jain, 2000). The CD also asked for permission to contact his parents (Janin, 2000). Sanjay did not give permission for his parents to be contacted. He felt that being with his family over break would help but would contact the Complex Director if he felt suicidal (Jain, 2000). Approximately one week after returning from Thanksgiving break, Sanjay Jain took his life by running the moped in his residence hall room (Jain, 2000).

Sanjay's father, Uttam Jain brought suit against the University of Iowa claiming negligence. Uttam claimed that the University of Iowa did not follow policy to contact parents if a student attempts suicide and “that the university's knowledge of Sanjay's mental condition or emotional state requiring medical care created a special relationship giving rise to an affirmative duty of care toward him" (Jain, 2000, p. 297).

\section{Analysis}

Jain's claim of a special relationship was based on $\S 323$ of the Restatement (Second) of Torts (Jain, 2000). This section reads:

One who undertakes, gratuitously or for consideration, to render services to another which he should recognize as necessary for the protection of the other's person or things, is subject to liability to the other for physical harm resulting from his failure to exercise reasonable care to perform his undertaking, if (a) his failure to exercise such care increases the risk of such harm, or (b) the harm is suffered because of the other's reliance upon the undertaking. (Restatement (second) of Torts, 1965, p. 135)

Jain argued that the University of Iowa's failure to notify them of Sanjay's suicide attempt prevented access to care (Jain, 2000). The court found that the actions of the RAs 
and Complex Director did not result in any increased risk of harm to Sanjay (Jain, 2000). The court also noted instead of relying on services, Sanjay neglected to use any of the resources offered (Jain, 2000). Based on this the court ruled that a special relationship did not exist (Jain, 2000).

Given the absence of a special relationship to support a duty, Jain v. State of Iowa relied on the superseding-intervening act doctrine to find that the University of Iowa was not liable. This simply means that the act of suicide is an intervening act that prevents a finding of negligence (Alexander \& Alexander, 2011; Fossey \& Moore, 2010). Although Bogust v. Iverson was not cited in Jain there is congruence in the rulings.

\section{Schieszler v. Ferrum College}

Michael Frentzel was enrolled at Ferrum College. During his first semester he had conduct issues that resulted in completing an anger management program and meetings with the Dean of Student Affairs, David Newcombe to continue at Ferrum (Schieszler, 2002). Early in the spring semester, residence hall staff was alerted to an argument between Michael and his girlfriend, Crystal. Crystal reported that Michael was planning to hang himself. Michael presented with bruises to his head and neck and reported that they were due to self-harm (Schieszler, 2002). Campus police responded and requested that Dean Newcombe be informed of the incident (Schieszler, 2002). Dean Newcombe met with Michael and had him sign a suicide contract promising to seek treatment and not commit self-harm (Schieszler, 2002).

A couple of days later, Crystal received an email expressing Michaels suicidal intent (Schieszler, 2002). Crystal shared the email with Ferrum staff (Schieszler, 2002). When a well being check was conducted, it was discovered that he had hung himself 
(Schieszler, 2002). Michael's aunt, LaVerne Schieszler brought suit claiming that Ferrum College had knowledge that the suicide was foreseeable and had a duty to prevent it (Schieszler, 2002).

\section{Analysis}

The U.S. District Court in Schieszler referenced §314A of the Restatement (second) of Torts to determine if there is a special relationship (Schieszler, 2000). §314A outlines situations when a duty to intervene may arise because of a special relationship (Restatement (second) of Torts, 1965; Schieszler, 2000). The use of $\S 314$ also allowed the court to determine that the Bogust and Jain decisions were not relevant in this case because "they do not address whether a special relationship exists between the school and student. Rather both cases consider liability under Restatement (second) of Torts $§ 323$ (1965), a theory the plaintiff in this case abandoned at oral argument" (Schieszler, 2000, p. 608). The U.S. District Court also recognized that "the Virginia Supreme Court had not yet addressed the issue of whether a special relationship may arise between a university or college and a student" (Schieszler, 2000, p. 608). Not having precedent the court turns to college/university alcohol and hazing cases to examine rationale for and against finding a special relationship (Schieszler, 2000). The court determines that knowledge and foreseeability were factors in determining if a special relationship existed. The court notes that:

The conclusion that the relationship between a college or university and its students can give rise to a duty to protect students from harms of which the school has knowledge is consistent with the Virginia Supreme Court's analysis in other contexts. (Schieszler, 2000, p. 608-609) 
The court determined that the requirement of Michael to sign an agreement not to self-harm meant that Ferrum College staff had knowledge that he would likely attempt this act (Schieszler, 2000). The court found a special relationship existed and Ferrum College had a duty to protect Michael from committing suicide and the case could proceed to trial (Schieszler, 2000). However the case was settled before trial.

\section{Shin v. Massachusetts Institute of Technology}

Elizabeth Shin was a freshman at Massachusetts Institute of Technology (MIT). During spring semester Elizabeth was hospitalized for a drug overdose (Shin, 2005). Her parents were informed and worked with Elizabeth to arrange therapy at MIT (Shin, 2005). Elizabeth continued treatment upon returning for her sophomore year, however she began cutting and expressing suicidal ideation (Shin, 2005). During the spring semester Elizabeth was admitted to the MIT infirmary for self-harming (Shin, 2005). Her parents were notified and her father took Elizabeth home (Shin, 2005).

Elizabeth returned to MIT after spring break and continued therapy with a new physician (Shin, 2005). Students and hall staff often contacted the residence hall housemaster, Davis-Mills, regarding Elizabeth's behavior. Elizabeth continued therapy, often reporting that she felt overwhelmed (Shin, 2005). There were also conversations between MIT Support Services Dean Henderson and the physician regarding Elizabeth's mental health (Shin, 2005).

In early April, Elizabeth told another student that she planned to commit suicide (Shin, 2005). The student called campus police and Elizabeth was taken to the MIT Mental Health Center (Shin, 2005). Elizabeth was released. Two days later, Elizabeth again told students that she planned to kill herself (Shin, 2005). Davis-Mills 
(housemaster) contacted the MIT Mental Health Center and was told to keep an eye on Elizabeth (Shin, 2005). Davis-Mills followed up with Dean Henderson regarding the incidents and a worrisome conversation with Elizabeth (Shin, 2005). Dean Henderson reported that he would discuss Elizabeth at the "deans and psychs" meeting later that day (Shin, 2005). At the meeting it was determined that Elizabeth would have an appointment with off campus treatment center the next day (Shin, 2005). A message was left informing Elizabeth about this appointment (Shin, 2005). That evening a smoke detector in Elizabeth's room went off and she was discovered with her clothing on fire (Shin, 2005). Elizabeth never regained consciousness and was taken off life support a few days later (Shin, 2005).

Elizabeth's parents filed suit against MIT claiming breach of contract and negligence and emotional distress. The Shins claim that there was a contact between MIT and Elizabeth to provide medical care for her needs (Shin, 2005). The negligence claims were brought against physicians and student affairs personnel that had contact with Elizabeth (Shin, 2005).

\section{Analysis}

The Superior Court of Massachusetts first addressed the contractual issues. The court rules that a contract did not exist because wording in brochures and general statements from administrators "such statements are not definite and certain and too vague and indefinite to form and enforceable contact" (Shin, 2005, p. 7). The court also dismissed the emotional distress claim because the Shins were not present and did not suffer physical harm (Shin, 2005). The court ruled that the gross negligence claims against the physicians could go forward (Shin, 2005). The rationale was based on the 
failure of the physicians to execute a plan of care to respond to Elizabeth's mental health issues (Shin, 2005).

For the purposes of this chapter the relevant issue is the negligence claim against MIT student affairs staff. As in Schieszler, the court in Shin referenced §314A of the Restatement (second) of Torts to determine if there is a special relationship (Schieszler, 2000; Shin, 2005). In terms of precedents the court relies on Mullins v. Pine Manor College 389 Mass. 47; 449 N.E.2d 331(1983), a sexual assault case, and Schieszler. It is interesting to note that the court referenced discussion in Mullins v. Pine Manor regarding consideration of "social values and customs" in duty determination (Shin, 2005, p. 12) yet focused on foreseeability in the duty decision.

The plaintiffs have provided sufficient evidence that Henderson and Davis-Mills could reasonably foresee that Elizabeth would hurt herself without proper supervision. Accordingly there was a "special relationship" between the MIT Administrators, Henderson and Davis-Mills, and Elizabeth imposing a duty on Henderson and Davis-Mills to exercise reasonable care to protect Elizabeth from harm. (Shin, 2005, p. 13).

The Shin case was allowed to proceed to trial but was settled out of court.

\section{Mahoney v. Allegheny College}

Chuck Mahoney enrolled in Allegheny College as a freshman in fall 1999

(Mahoney, 2005). During football camp he experienced a panic attack and received care at the campus counseling center (Mahoney, 2005). Although he did not play football in the fall, Chuck practiced with the team during the spring semester (Mahoney, 2005). He continued to be seen at the counseling center for anxiety issues during his freshman year, 
he joined a fraternity and had a girlfriend, Kristen (Mahoney, 2005).

Chuck returned for football practice and the start of his sophomore year (Mahoney, 2005). Early in the fall of 2000, Kristen brought Chuck to the counseling center because he expressed the desire to harm himself (Mahoney, 2005). At this point Chuck was hospitalized and his parents were notified (Mahoney, 2005). Chuck was treated and cleared to return to campus where he continued to be seen at the counseling center (Mahoney, 2005).

Chuck returned to Allegheny College for football camp and his junior year. He decided to quit the team and break up with his girlfriend, Kristen (Mahoney, 2005). Chuck admitted to his therapist that although his grades were good, he was a closet drinker and had a problem with alcohol (Mahoney, 2005). His therapist felt that Chuck was increasingly depressed and at risk of self-harm (Mahoney, 2005). She requested several times to have permission to contact his parents; which Chuck would not grant (Mahoney, 2005).

In January of his junior year, Chuck told his former girlfriend, Kristen, and Adam, one of his fraternity brothers to take care of his dog if anything happens (Mahoney, 2005). Kristen and Adam met with Chuck's therapist to make her aware of this and other concerns (Mahoney, 2005). Chuck's fraternity brothers also shared concerns with the dean of students office. Dean DiChristina and Associate Dean Mitchell were made aware of a conflict in the fraternity between Chuck and another member who is dating Kristen (Mahoney, 2005). DiChristina and Mitchell did not feel that the issue needed to go to student conduct. Chuck's therapist alerted DiChristina about his mental health issues but also stated that contacting parents or an involuntary leave would make matters worse 
(Mahoney, 2005).

On February 11, 2002 Chuck hung himself at the fraternity house (Mahoney, 2005). Chuck's parents brought suit claiming that Allegheny College had a duty to protect their son from suicide and to contact them about his mental state (Mahoney, 2005).

\section{Analysis}

Mahoney is the first of the cases discussed in this chapter to define all of the factors that should be considered in a duty determination. These factors include

1) The relationship between parties, 2) the social utility of the defendants conduct, 3) that nature of risk imposed and foreseeability of harm incurred, 4) the consequences of imposing a duty upon the defendant, and 5) the overall public interest in a proposed solution. (Mahoney, 2005, pp. 14-15)

The court also emphasizes that it is the totality of factors, not just a focus on one or two, for a determination of duty (Mahoney, 2005).

Noting that there is an absence of Pennsylvania law to rely on for precedent, the court considered the Shin, Schieszler and Jain cases. The Mahoney court declined to follow Shin and Schieszler for several reasons:

1. Since the cases were settled out of court they are of limited value for precedent.

2. The focus on foreseeability limited the applicability to the facts in Mahoney.

3. The court viewed the special relationship determination in Shin and Schieszler as a form of in loco parentis that could lead colleges/universities to be reactive rather than proactive (Mahoney, 2005).

The court turned its attention to Jain and focused on the analysis that the actions 
of University of Iowa staff did not result in an increased likelihood of self-harm (Jain, 2000; Mahoney, 2005). Similarly the court felt that the actions of Dean DiChristina and Associate Dean Mitchell did not increase the likelihood of Chuck committing suicide (Mahoney, 2005). The court also determined that the suicide was an intervening event thus following the decisions of Bogust v. Iverson and Jain (Mahoney, 2005). However the court does issue a warning to institutions of higher education:

Failure to create a duty is not an invitation to avoid action. We believe the "University" has a responsibility to adopt prevention programs and protocols regarding students self-inflicted injury and suicide that address risk management from a humanistic and therapeutic as compared to just a liability or risk avoiding perspective...Rather than create an ill-defined duty of due care the University and mental health community have a more realistic duty to make strides toward prevention. (Mahoney, 2005, p. 25)

This warning is evidence of the courts concern that a determination of duty would increase stigma for students with mental health concerns (Mahoney, 2005).

\section{Bash v. Clark College}

Michelle Bash enrolled in Clark University in the fall of 2003. In keeping with Clark on-campus residence hall policy she moved into Johnson Hall (Bash, 2006). During her first semester, Michelle was documented for underage drinking and the campus police responded to an incident and found her intoxicated (Bash, 2006). Michelle's parents also became concerned about drug use after reading some of her internet posts (Bash, 2006). Her father shared his concerns with the campus counseling staff (Bash, 2006). Michelle denied using drugs during a meeting with the interim dean of students, 
Denise Darrigand (Bash, 2006).

Michelle returned to Clark for the spring semester on academic probation and was assigned to meet with an academic advisor (Bash, 2006). The advisor held three meetings with Michelle and suggested that she seek assistance at the counseling center (Bash, 2006). The advisor's concerns were not shared with anyone other than Michelle (Bash, 2006). In conjunction with an investigation of drug use on campus, Michelle had a

meeting with Darrigand and associate dean of students, Julianne Ohotnicky, during which she admitted trying heroin (Bash, 2006). Darrigand informed Michelle's mother of the heroin use (Bash, 2006). On March 1, 2004 Michelle was again documented for being agitated and drinking (Bash, 2006). Later that day she received heroin from another Clark student and was found unresponsive in her residence hall room the next morning (Bash, 2006). Michelle's father filed a wrongful death suit against Clark University alleging a duty to protect his daughter (Bash, 2006).

\section{Analysis}

Although one may argue that the Bash case is an outlier in this chapter, the courts deliberation on duty is relevant to the discussion. The court utilizes Mullins v. Pine Manor, Shin and Schieszler among other cases for guidance in determining if there was a duty to protect Michelle (Bash, 2006). In contrast to the reliance on foreseeability in Shin and Schieszler, the court in Bash clearly states "the foreseeability of physical harm is not the linchpin for determining the existence of common-law duty under Massachusetts tort law. Instead the question of duty is determined by a consideration of existing social values, customs and considerations of policy" (Bash, 2006, p. 10).

The court also references Mullins v. Pine Manor in which a distinction was made 
between the responsibilities to provide a secure building to protect a student versus "responsibility for moral well being of students" (Bash, 2006, p. 15). It was felt that Michelle's use of heroin fell clearly under moral well-being and out of the prevue of Clark University (Bash, 2006). The court also applies a balancing test weighing potential harm of injury from drugs with the burden on a college/university to protect a student from that harm (Bash, 2006; Romantz \& Vinson, 2009). The court had "grave reservations about the capacity of any university to undertake measures to guard against the risk of death or serious injury due to the voluntary consumption of drugs other than those provided by or with the approval of the university" (Bash, 2006, p. 13). In light of these factors the court dismissed the suit against Clark University (Bash, 2006).

\section{Did The Courts Err in Schieszler and Shin?}

In Bradshaw v. Rawlings 612 F2d 135 (1979) the court states "the modern American college is not an insurer of the safety of its students" (138). Schieszler and Shin courts indicated that they expect the college/university to insure the safety of students when they are a threat to self. In reaching this determination both courts focused on foreseeability (Schieszler, 2002; Shin, 2005). It is this focus that has some legal scholars expressing the opinion that the courts got it wrong (Dyer, 2008; Fossey \& Moore, 2010; Lapp, 2010; Moore, 2007).

\section{§314 v. §323 Restatement (Second) of Torts}

Under $\S 323$ the court determines liability only if actions taken result in harm of a greater magnitude than no action being taken or if the plaintiff placed him/herself in the care of another to the exclusion of seeking other avenues for assistance (McAnaney, 2008; Restatement (second) of Torts, 1965). The courts in Jain and Mahoney relied on 
$\S 323$ for their lens of determination of a special relationship imposing a duty with the decision that actions of employees of the university did not increase the likelihood of self-harm or prevent other sources of care (Jain, 2000; Mahoney, 2005).

In contrast the courts in Schieszler, Shin and Bash rely on $\S 314$ for determination of a special relationship imposing a duty (Bash, 2006; Schieszler, 2002; Shin, 2005). In $\S 314:$

The general rule states that the actor realizes or should realize that his action is necessary for that aid or protection of another does not in itself impose upon him any duty to act... The duties... arise out of special relations between the parties, which create a special responsibility, and take the case out of the general rule...The defendant is not required to take any action until he knows or has reason to know the plaintiff is endangered, or is ill or injured. (Restatement (second) of Torts, 1965, p. 119-120)

An examination of the facts in Schieszler and Shin would lead to the conclusion that knowledge that a person was in danger existed (Schieszler, 2002; Shin, 2005). In Bash the examination of fact led to the conclusion that such knowledge did not exist (Bash, 2006). Thus one could surmise that the use of $\S 314$ was appropriate for the facts of the cases. However this is only the beginning point of a determination of duty.

\section{Balancing Foreseeability and Burden}

The Schieszler court cited Virginia case law that called for balancing the likelihood of injury with burden of protecting against injury (Dyer, 2008; Schieszler, 2002). However it does not appear that the court considered this balancing test in reaching its decision. The focus is on what the defendants knew and could expect to 
happen without discussion of the burden to prevent it (Schieszler, 2002).

Bash and Shin were both heard in the Superior Court of Massachusetts and the Bash case serves to illuminate the shortcomings of Shin. For example the Bash court discussed that under Massachusetts tort law foreseeability is not a lone factor in duty determination (Bash, 2006). Yet the Shin court had tunnel vision when it came to foreseeability without any attempt to balance the burden of protecting a student from harm. (Shin, 2005).

The balance of foreseeability and burden is also a reason that the Mahoney court moved away from Schieszler and Shin. In discussing the factors of a duty decision; relationship, foreseeability, social norms and values, etc.; the court also states "none of the factors is dispositive, but rather a duty will be found to exist where the balance of factors weighs in placing such a burden on the defendant" (Mahoney, 2005, p. 15). Thus one could argue that the courts in Schieszler and Shin did not expend enough effort on examining all of the factors of a duty determination and the consequences of creating a burden on the university (Dyer, 2008; Lake, 2008; Lapp, 2010; McAnaney, 2008).

\section{Limited Precedential Value}

Instead of continued discussion of error, time is better spent to put Schieszler and Shin in context. Both cases were in court to determine if there was justification for a trial. It is possible that the short comings/errors discussed would have been resolved at trial. However this is all conjecture since the cases were settled before a trial began (Lake, 2008; Pavela, 2012).

Although the Schieszler and Shin cases garnered a lot of press and resulted in institutional risk management practices that focused more on liability than student 
development, the circumstances of the cases are very narrow (Dyer, 2008; Lake, 2008; Lapp, 2010; Pavela, 2012). In fact the plaintiff's lawyer in Shin felt that the case was of limited generalizability stating, "there is not the sense from this ruling that a university administrator has an absolute duty to ensure the safety of all students under all circumstances" (Moore, 2007, FN 116 citing Hoover). Although the court in Bash distinguishes the self-harm in drug use as being different from suicide, the message is that institutions of higher education cannot monitor the activities of students at all times (Bash, 2006; Lapp, 2010). Thus Schieszler and Shin are applicable in a situation when a known risk of self-harm is imminent and not taking action will result in injury or death (Lapp, 2010; Pavela, 2012). To further put Schieszler and Shin in context is to note that no court to date has followed their ruling (Fossey \& Moore, 2010; Kalchthaler, 2010).

\section{Message In Mahoney}

The court in Mahoney accurately predicted the fallout of a special relationship determination in Shin by noting:

Concomitant to the evolving legal standards for a "duty of care" to prevent suicide, are the legal issues and risks associated with violations of therapistpatient privilege, student right of privacy and the impact of "mandatory medical withdrawal policies" regarding the civil rights of students with mental disability. In effect, now that proximate causation is no longer outcome determinative, courts are facing a multiplicity of public policy issues involving legal and ethical dilemmas of student privacy and welfare concerns within the context of causes of action involving the best interest and rights of students, parents and the University. (Mahoney, 2005, p. 20). 
In laying out this balance test the court recognizes that imposing a duty will be a disincentive colleges/universities to be proactive with students who are at risk of selfharm (Lapp, 2010). Further the court imposes a balancing test on institutions of higher education to balance risk management policy with student development (Blanchard, 2014). As will be discussed in chapter six, institutions of higher education have policies and programs at their disposal to appropriately intervene. The courts since Schieszler and Shin have given every indication that suicide is an intervening event and the fear of litigation should not prevent a college/university from helping its students (Bash, 2006; Lake, 2009 \& 2013; Lapp, 2010; Mahoney, 2005; Pavela, 2012). 


\section{CHAPTER V}

\section{TITLE II OF THE AMERICANS WITH DISABILITIES ACT AND}

SECTION 504 OF THE REHABILITATION ACT OF 1973

Schieszler and Shin scared higher education with the decision that a special relationship existed (Appelbaum, 2006; Lapp, 2010; Pavela 2006 \& 2010). According to Pavela (2006) after Shin "a common reaction - expressed on professional Listservs and at conferences - is that students should promptly be dismissed, preferably on medical grounds" (p. 367). As discussed in chapter four Schieszler and Shin fit very narrow circumstances and have not be relied on for precedent in other cases. However the practice of involuntary medical withdrawals continues despite changes to the Americans With Disabilities Act (ADA) and the consequences of violating federal law.

\section{Nott v. George Washington University}

In chapter two the reader was briefly introduced to Jordan Nott who as a George Washington University (GWU) student seemingly did everything right when having a mental health issue (Nott, 2005). During the fall semester of 2004, Jordan was being treated for anxiety after a college friend committed suicide (Nott, 2005). Jordan thought that he was having a reaction to anxiety medication and sought help at the GWU Hospital (Nott, 2005). While in the hospital, Jordan was informed by a representative from GWU that he was unable to return to living in the residence hall and was under interim suspension for violating the conduct code for "behavior of any kind that imperils or 
jeopardizes the health or safety of any person or persons... This includes any actions that are endangering to self or others" (Nott, 2005, paragraph 41). He was also told that a disciplinary hearing would take place in less than seven days and sanctions could include expulsion (Nott, 2005).

After being discharged from the hospital, Jordan and his mother met with a GWU administrator to discuss options (Nott, 2005). They were presented with the option to withdraw or face suspension or expulsion; no other alternatives, such a moving off campus were presented or explored (Nott, 2005). Jordan and his parents made the decision to withdraw from GWU. He received a letter from GWU confirming the mental health withdrawal, the code of conduct charges were deferred and that he was barred from campus (Nott, 2005). In order to return to GWU, Jordan must have:

Successfully completed all prescribed medical treatment, and provided medical documentation that he has been symptom free for six months and had the ability to live independently and to perform successfully in a university environment. If he met those terms and complied with the barring order, after April 29, 2005 he could request clearance from the University Counseling Center. If and when clearance was recommended, [GWU] would consider reexamining the case and dropping the pending charges. (Nott, 2005, paragraph 62). Jordan decided in the spring of 2005 to permanently withdraw from GWU. He sent a letter informing the institution of his decision and requested that he no longer be trespassed from campus so that he could visit friends (Nott, 2005). He received a letter stating that all the stipulations to return from his mental health withdrawal remain in place and he could visit his friends off campus (Nott, 2005). Jordan Nott filed suit against 
GWU and the suit was settled out of court.

\section{Title II of the Americans with Disabilities Act and Section 504 of the Rehabilitation Act of 1973}

Unfortunately Nott's plight is not an isolated incident (Lapp, 2010; Stuart, 2012). The Department of Justice (DOJ) has given the Department of Education Office of Civil Rights (OCR) jurisdiction to administer and investigate violations of Title II of the Americans with Disabilities Act (ADA) and Section 504 of the Rehabilitation Act of 1973 (Lannon \& Sanghavi, 2011; Grace \& Smith, 2014). Section 504 applies to public and private educational institutions. OCR has translated it in a similar manner to Title II, which applies to public institutions (Lannon \& Sanghavi, 2011; Grace \& Smith, 2014). Which meant that prior to 2011, college/universities could remove students from campus who were a direct threat to self or others (Lannon \& Sanghavi, 2011). Although this appeared to be a discriminatory practice, the OCR Letter to Woodbury University, (Complaint Number 09-00-2079, June 29, 2001) contains the following:

Compared to the issue of persons seen as a threat to others, the issue of persons who are a threat to self has seldom been addressed under the Rehabilitation Act. Prior OCR letters addressing this type of threat have supported intervention by colleges and universities when they have tailored the scope of the intervention to the particular circumstances of the case. (p. 4)

Written just four years later the OCR Letter to Marietta College, (Complaint \# 1504-2060, March 18, 2005) reads the law "does not prohibit a postsecondary education institution from taking action to address an imminent risk of danger posed by an individual with a disability who represents a direct threat to the health and safety of 
himself/herself or others" (p. 3). The letter continues that a direct threat is defined as "a high probability of substantial harm and not just a slightly increased, speculative, or remote risk" (p. 3). This position was consistent with the Equal Employment Opportunity Commission that was upheld by the U.S. Supreme Court in Chevron v. Echazabel 536. U.S. 73,76 (2002) (Lannon, 2014). $\$ 35.104$ of the ADA defines how a direct threat is determined:

It must be based on an individualized assessment, based on reasonable judgment that relies on current medical evidence or on the best available objective evidence, to determine: the nature, duration, and severity of the risk; the probability that the potential injury will actually occur; and whether reasonable modifications of policies, practices, or procedures will mitigate the risk. (ADA, 1991, np)

OCR letters are not formal policy statements but they do provide guidance on how the legislation should be implemented. OCR letters to Guilford College (Complaint \#1-1-02-2003, March 6, 2003), Bluffton University (Complaint \# 15-04-2042, December 22, 2004), and Marietta College (Complaint \# 15-04-2060, March 18, 2005) demonstrate that all of the criteria are analyzed to determine if a college/university exercised due diligence before removing a student for being a direct threat.

According to GWU, Jordan Nott was a direct threat to the residence hall community in which he lived (Nott, 2005). Applying the ADA direct threat definition and analysis illuminates where GWU erred in this determination.

\section{Individualized Assessment}

According to the OCR letter to Bluffton there should be "consultation with medical personnel and examination of objective evidence to ascertain nature, duration 
and severity of risk" (OCR, 2004, p. 5). In the case of Jordan Nott, he sought out and was compliant with treatment for anxiety (Nott, 2005). He was not suicidal or exhibiting selfinjury behavior and voluntarily sought help for a severe medication reaction (Nott, 2005).

\section{Due Process}

According to the OCR (2003) letter to Guilford "colleges must take steps to ensure that disciplinary and other adverse actions against persons posing a direct threat are not a pretext or excuse for discrimination" (p. 10). GWU decided to interim suspend and conduct a discipline hearing before any medication determination of Jordan's ability to successfully navigate college life could be determined (Nott, 2005). Further scheduling the hearing while Jordan was hospitalized and not responding to a request for an extension did not provide for the ability to respond to the violations of the code of student conduct (Nott, 2005;). Jordan and his parents were not told of the right to appeal or given information regarding the procedure to file a disability discrimination complaint (Nott, 2005; OCR, 2005).

\section{Reasonable Modifications Will Mitigate the Risk}

According to the OCR letter to Marietta there should be "consideration whether the perceived risk could have been mitigated by reasonable modifications of College policies, practices or procedures (OCR, 2005, p. 5). In the case of Jordan Nott the alleged violation of the code of student conduct applied only to the residence hall (Nott, 2005). There was never a discussion of another living arrangement that would allow Jordan to remain enrolled at GWU (Nott, 2005).

"Direct threat analysis in itself is painstaking, highly individualized and contextual, including analysis of various settings in which the student may be situated, 
and the requirement to consider reasonable accommodation" (Pavela, 2006, p. 369). In light of the lacking analysis, it is evident why GWU chose to settle the suit out of court. The terms of the settlement were confidential, however GWU did agree to make changes to policies regarding students with mental health issues (Bazelon Center for Mental Health, 2006).

\section{Virginia Law}

Changes to GWU policy were not the only legacy of the Jordan Nott case. In early 2007 the Virginia legislature unanimously passed a bill, ultimately signed into law that barred state universities from punishing students for self-harming behavior or seeking help with mental health issues (Keller, 2007; McAnany, 2008; Penven \& Janosik, 2012; Reinberg, 2007). The bill's sponsor stated that the plight of Jordan Nott was the inspiration for the legislation (Keller, 2007). The bill read:

The governing boards of each public institution of higher education shall develop and implement policies that advise students, faculty and staff, including residence hall staff, of the proper procedures for identifying and addressing the needs of students exhibiting suicidal tendencies or behavior. The policies shall ensure that no student is penalized or expelled solely for attempting to commit suicide or seeking mental health treatment for suicidal thoughts or behaviors. (Reineberg, 2007)

The response from Virginia public colleges/universities was of concern that the legislation would curtail options when working with a student of concern (Keller, 2007; Reineberg, 2007). Some legal scholars felt that the Virginia legislation was a good beginning but needed to be more specific regarding what penalties should be prohibited. 
"In particular, the statute should make clear that the university may require a student to seek appropriate mental health treatment or counseling before returning to the university setting” (McAnany, 2008, p. 240).

The question to be asked is: Did §23-9.2:8 influence policy on Virginia’s colleges/universities? Two-year and four-year institutions, both public and private, were surveyed regarding practices and policies to respond to student mental health issues in 2008-2009 (Monahan, Bonnie, Davis \& Flynn, 2011). According to the survey almost half of public four-year institutions and close to all private four-year institutions had mandatory medical leave policies that covered mental health issues (Monahan, et al., 2011). Additional findings included:

Rates of voluntary medical withdrawal at public and private colleges were comparable, but the rate of receiving treatment at the counseling center as part of a disciplinary sanction was five times higher and the rate of monitoring by a threat assessment team was three times higher at private than at public colleges. (Monahan, et al., 2011, p. 1442)

Reasons cited by the authors for the differences included more student services staff at private institutions and "greater willingness by private colleges to take a hands-on protective stance toward the well-being of students" (Monahan, et al., 2011, p. 1442). Although not mentioned by the authors, $\$ 23-9.2: 8$ could have contributed to these results. Section 23-9.2:8 of the Virginia code was modified in 2012 and 2013. In 2012 the provision that " no student is penalized or expelled solely for attempting to commit suicide or seeking mental health treatment for suicidal thoughts or behaviors" was removed and provision for training was added (Code of Virginia, 2012, np). The statute 
read:

The governing boards of each public institution of higher education shall develop and implement policies that advise students, faculty, and staff, including residence hall staff, of the proper procedures for identifying and addressing the needs of students exhibiting suicidal tendencies or behavior and provide for training, where appropriate. (Code of Virginia, 2012, np)

In 2013 an additional section was added:

The governing board of each public four-year institution of higher education may establish a written memorandum of understanding with its local community services board or behavioral health authority and with local hospitals and other local mental health facilities in order to expand the scope of services available to students seeking treatment. The memorandum shall designate a contact person to be notified when a student is involuntarily committed, or when a student is discharged from a facility and consents to such notification. The memorandum shall also provide for the inclusion of the institution in the post-discharge planning of a student who has been committed and intends to return to campus, to the extent allowable under state and federal privacy laws. (Code of Virginia, 2013, np)

These changes stem from the Virginia Tech Shooting in 2007 which lead to comprehensive mental health reform in the state of Virginia and nation wide development of college/university threat assessment and behavioral intervention practices (Bonnie, Reinhard, Hamilton \& McGarvey, 2009; Lewis, Schuster \& Sokolow, 2012; Penven \& Janosik, 2012). 


\section{Change to Direct Threat Provision}

In 2010 the Department of Justice (DOJ) made a change to the direct threat standard in Title II of the Americans with Disabilities Act (Grasgreen, 2014; Lannon \& Sanghavi, 2011; Lewis, et al., 2012). § 35.139 now reads:

(a) This part does not require a public entity to permit an individual to participate in or benefit from the services, programs, or activities of that public entity when that individual poses a direct threat to the health or safety of others. (ADA.Gov, 2010, np)

The change in wording makes the direct threat provision identical in Title II and III of the ADA (Lewis, et al., 2012). Injury to self as part of a direct threat provision remains in Title I and is consistent with DOJ's belief that self-harm should be an employment concern (Colker \& Grossman, 2014; Lewis, et al., 2012). It has also been suggested that DOJ made this change because colleges/universities used "the broader language as a tool to kick suicidal students out pretextually, prematurely or presumptively" (Lewis, et al., 2012, p. 4).

The wording change was implemented in March 2011. In late 2011 and early 2012 the National Association of Student Personnel Administrators (NASPA) and the National Association of College and University Attorneys (NACUA) requested, in person and via written communication, for OCR to provide guidance how institutions should respond to students who are a threat to self (Lannon, 2014; Lewis, et al., 2012). In the absence of any formal guidance on the topic to date, OCR decision letters and resolution agreements are the only documents that colleges/universities have as resources for policies and actions consistent with changes in legislation. It should be remembered that 
OCR has translated Section 504 in a similar manner to Title II, as such decision letters addressing Section 504 and Title II offer relevant information and guidance (Lannon \& Sanghavi, 2011; Grace \& Smith, 2014).

\section{Spring Arbor University}

The Spring Arbor University decision (OCR Docket \#15-10-2098) was released after the Title II wording was changed but before it had been implemented (Lannon, 2014; Lewis, et al., 2012). In this complaint a male student transferred to Spring Arbor University. Although diagnosed with bipolar disorder, he did not register with the disability resource center. During fall semester he adjusted to a new medication and experienced episodes of cutting (OCR, 2010). These incidents were brought to the attention of the Resident Director (RD). The RD scheduled a meeting with the complainant, the Vice President for Student Affairs (VPSA) and the Assistant Vice President for Student Affairs (AVPSA) (OCR, 2010). The student is told that the purpose of the meeting was to discuss ways for him to succeed in college. During the meeting the complainant was told about complaints regarding his behavior and presented with a behavior contract to sign and follow (OCR, 2010). The student became agitated and expressed a desire to voluntarily medically withdraw (OCR, 2010).

The complainant sought readmission and was told by Spring Arbor that he must submit a 504 plan or at a minimum provide treatment records indicating he can be successful in college (OCR, 2010). During a conversation with the complainant, an admissions counselor disclosed that 504 plans are not required of other students seeking readmission (OCR, 2010). The complainant also requested a waiver to be able to live off campus to be able to manage his condition (OCR, 2010). The VPSA denied the request 
for off campus housing and readmission (OCR, 2010).

In analysis of the situation OCR writes that the direct threat standard only applies when the individual is a threat to others (Lannon, 2014; Lewis, et al., 2012; OCR, 2010). OCR also applies disparate treatment analysis to the complaint. Honing in on the fact that a 504 plan has only been required from students seeking readmission stemming from a mental health issue, OCR finds that Spring Arbor University acted in a discriminatory manner in denying readmission to the student (Lannon, 2014; Lewis, et al., 2012; OCR, 2010).

It should be noted that when the complainant left Spring Arbor he was not facing any disciplinary issues and was in good academic standing (OCR, 2010). However the AVPSA "noted that the Complainant was a disaster from an emotional control standpoint...the University could assert that he was a danger to himself and disruptive to others" (OCR, 2010, p. 8). In the analysis OCR found that an individualized assessment had not been conducted to determine if the student was a threat to others (Lannon, 2014; OCR, 2010).

As a result of the complaint Spring Arbor University agreed to refund tuition to the student for courses that did not transfer to his new institution (OCR, 2010). The investigation also found that policies applying to readmission are not listed in one common location (OCR, 2010). For example a policy was listed on the web site but not in the student handbook (OCR, 2010). Spring Arbor University was advised to remedy this and to revise grievance policies in the student handbook to provide notice that students can appeal decisions (OCR, 2010). From the Spring Arbor University it appears that when students are a threat to self instead of applying direct threat analysis, it becomes a 
determination of similarly situated students treated similarly (Lannon, 2014; Lewis, et al., 2012).

\section{State University of New York at Purchase}

Approximately one month after the Spring Arbor University decision OCR released a decision regarding a similar complaint against State University of New York at Purchase (SUNY Purchase) (OCR Case No. 02-10-2181). In this complaint a male student diagnosed with bipolar disorder believed that he was discriminated against by being placed on medical leave from SUNY Purchase (OCR, 2011).

The complainant was brought to the hospital by the police following an overdose of medication in a suicide attempt (OCR, 2011). Following release the complainant was notified that he must comply with the Policy Regarding Return to Campus After Emergency Medical Evaluation/Treatment by scheduling an assessment at the campus counseling center (OCR, 2011). According to the policy any student who receives emergency medical treatment must schedule an appointment at the health center for an illness/accident or the counseling center for psychological/alcohol/drug related incident (OCR, 2011). The purpose of the policy is to plan for continued treatment and any needed academic/residential accommodations (OCR, 2011).

The complainant complied with the policy and completed an assessment at the campus counseling center. The psychologist provided a report to the Associate Dean with the recommendation that the complainant not return at the time (OCR, 2011). The Associate Dean shared this information with the complainant, including the treatment recommendations (OCR, 2011). The complainant was advised that he could comply to be placed on voluntary leave or not agree and be placed on involuntary leave (OCR, 2011). 
According to SUNY Purchase:

Involuntary medical leave of absence applies to any student whose behavior renders them unable to effectively function in the residential or college community without harming themselves, others, or disrupting the college community and who refuse and/or cannot be helped by emotional and/or medical treatment. (OCR, 2011, p. 2).

The Associate Dean also included information about appealing the decision and the complainant agreed to a voluntary leave of absence (OCR, 2011).

As in the Spring Arbor University investigation, OCR applied disparate treatment analysis to this complaint. OCR determined that SUNY Purchase did not discriminate because the policies applied to all students who were hospitalized due to an emergency (Lannon, 2014; OCR, 2011). In contrast to Spring Arbor University, SUNY Purchase had clearly written policies that were followed, an individualized assessment was conducted and opportunity for appeal provided (Lannon, 2014; OCR, 2011).

\section{St. Joseph's College}

A female complainant alleged discriminatory practices when she was dismissed from St. Joseph's College (OCR Case Number 02-10-2171, January 24, 2011). The complainant grabbed and kissed a male student, only letting go of him when forced by campus security (OCR, 2011). The complainant was interim suspended from campus for this incident and was allowed to return a week later after providing documentation from her psychiatrist (OCR, 2011). Upon her return, the complainant was told to have no contact with the male student (OCR, 2011). A week later, the complainant again grabbed the student and had to be forcibly separated from him (OCR, 2011). 
Following the second incident the complainant was hospitalized and the St Joseph's College Behavioral Assessment Committee (BAC) met and placed her on emergency suspension. The BAC based this decision on the behavior of the complainant, statements from faculty and staff and the letter from the psychiatrist following the first incident (OCR, 2011). The complainant was unaware that the BAC had met to discuss her behavior until she received a letter from the Dean of Students regarding the emergency suspension and "that her case would be reviewed and she would be notified of the result" (OCR, 2011, p. 3). According to OCR review of the St. Joseph's College policy for emergency suspension in non-academic matters:

Pursuant to these guidelines the Dean of Students, the Academic Dean or their delegates may summarily suspend a student in an emergency or extraordinary situation for up to ten days. The Student Judicial Committee (SJC) will convene and conduct a hearing during the ten-day period of the student's suspension. The SJC's recommendation must be approved by a majority of the President's Council and that a student may appeal the decision to the College President. (OCR, 2011, p. 3)

There is also a policy that reads "a student who is the subject of a hearing receive notice, including names of witnesses expected to testify; assistance by an advisor of their choosing; and the opportunity to testify, present evidence and witnesses, and question adverse witnesses" (OCR, 2011, p. 3).

Approximately 40 days after receiving notice of the suspension, the complainant contacted St. Josephs College regarding the ability to return to campus (OCR, 2011). A BAC meeting was held and the decision was made to continue the complainants 
suspension because of violations of the code of student conduct (OCR, 2011). Note that is was the behavioral assessment committee not the conduct committee making this determination. Approximately six weeks later the complainant's father contacted the college to make an appeal for a return to campus. The Dean of Students contacted the BAC members who again decided to continue the suspension (OCR, 2011).

OCR conducted an investigation and determined that St. Joseph's College did not follow its own policies and in addition did not have any written policies regarding the BAC (Lewis, et al., 2012; OCR, 2011). In addition the OCR found that similarly situated students were not treated similarly because the other incidents where the BAC was used instead of a conduct hearing involved students with mental health issues (Lewis, et al., 2012; OCR, 2011). As a result St. Joseph's must provide written policies regarding the use of the $\mathrm{BAC}$, provide a process to appeal $\mathrm{BAC}$ decisions and show that the $\mathrm{BAC}$ process addresses all student behaviors not just students with a disability (Lewis, et al., 2012; OCR, 2011).

\section{Western Michigan University}

Jackson Peebles filed an OCR complaint for an involuntary withdrawal after being treated for suicidal ideation (Cantero 2011a \& 2011b; Grasgreen, 2014). In February 2013, Peebles, who had been diagnosed with depression and anxiety, was hospitalized for a week over concerns that he may be suicidal (Cantero 2011a \& 2011b). A week after being discharged from the hospital Western Michigan University notified him that he would be withdrawn from classes and would not allow him back into the residence halls because he was a threat to self (Cantero 2011a \& 2011b; Grasgreen, 2014). 
Peebles filed an appeal, following Western Michigan University process, and was granted the ability to return to campus in March of 2013 (Cantero 2011a \& 2011b). However he still chose to file a complaint because "I want the university to genuinely try to make their process better when it comes to situations like this" (Cantero 2011a, n.p.). The complaint was investigated by the OCR with the outcome that Western Michigan University revise its policy (Cantero 2011a \& 2011b; Grasgreen, 2014). Less than a month after receiving the outcome of the complaint and eight months after being involuntarily withdrawn, Peebles committed suicide (Cantero 2011a \& 2011b; Grasgreen, 2014). A spokesperson for Western Michigan University stated "on our campus, we are working hard to find the right balance between addressing the current OCR interpretation of the law and doing what we know is the right thing for the well-being of our students" (Grasgreen, 2014, n.p.).

\section{Finding the Right Balance}

Institutions of higher education may be between a rock and a hard place when it comes to balancing the needs of students who are experiencing active mental health issues and maintaining a safe community for learning (Baker, 2014). Responding to an inquiry from Newsweek Magazine a spokesperson from OCR "that it understands that there is a critical need for guidance addressing the rights and responsibilities of postsecondary institutions and students with mental-health related disabilities and added it was actively developing policy" (Baker, 2014, n.p.). While awaiting guidance from OCR there are some lessons to be learned from the actions of the institutions that have been investigated. 
Disparate treatment analysis will be used in place of direct threat analysis when a student is a threat to self (Lannon, 2014; Lewis, et al., 2012). Colleges/universities should review policies to determine if the apply to both students with and without disabilities (Lannon, 2014; Lewis, et al., 2012). This includes conduct codes, sanctions, use of behavioral intervention and threat assessment teams (Lannon, 2014; Lewis, et al., 2012). Involuntary suspensions should be based on individualized assessments (Lannon, 2014; Lewis, et al., 2012). SUNY Purchase had a policy that applied to all students that provided for mandated assessment (Lannon, 2014; OCR, 2011). As stated the policy provided for the ability to plan for needed accommodations to keep a student on campus, it was not just a tool for removal of a student (OCR, 2011). It should be noted:

Institutions that respond to self-destructive behavior with actions that seem more calculated to limit liability than to address the needs of their students are likely to be vulnerable to allegations of disability discrimination under Section 504 as well as titles II or III of the ADA. (Colker \& Grossman, 2014, p. 15)

Last, but certainly not least, colleges/universities cannot have policies and practices that are separate from one another. Spring Arbor University and St. Joseph's College are clear examples of what happens when written policies are not followed. Also policies must provide for due process and ability appeal the decisions, including how to file a complaint with OCR (Lannon, 2014; Lewis, et al., 2012). There are times when an involuntary removal from campus is the right the decision. It is a decision that should be made based on the circumstances of the case and not a knee-jerk reaction. 


\section{CHAPTER VI}

\section{COLLEGE/UNIVERSITY POLICIES AND PRACTICES}

The court in Mahoney recognized that imposing a duty would be a disincentive for colleges/universities to be proactive with students who are at risk of self-harm (Lapp, 2010). The court further states "we believe the "University" has a responsibility to adopt prevention programs and protocols regarding students self-inflicted injury and suicide that address risk management from a humanistic and therapeutic as compared to just a liability or risk avoiding perspective" (Mahoney, 2005, p. 25). This sentiment is consistent with the changes to Title II of the ADA that send the message to institutions of higher education to respond with care rather than suspension (Colker \& Grossman, 2014). However "whatever strategies we come up with must also take into account the fact that many educational institutions, facing severe budget cuts, are struggling to cater to students who are not troubled, let alone those who are"(Roy, 2010, p. 100).

According to Bryson (2011) "a strategic issue is a fundamental policy question or challenge affecting an organization's mandates, mission and values, product or service level and mix, clients or users, cost financing, organization or management" (p. 185). Given the messages from the courts, changes in legislation, and increasing numbers of college students with mental health concerns (Castillo \& Schwartz, 2013; MacKean, 2011), colleges/universities need to recognize the emotional and mental health of all students as a strategic issue (Martel \& Sood, 2015). 


\section{Applying the Social Ecological Model}

When taking a strategic approach to underage drinking, colleges/universities that recognized the issue had multiple levels (individual, community, etc.) were more successful at affecting changes in behavior (DeJong, 2009; DeJong \& Langford, 2002). A similar approach would serve not only the student who is at a risk for self-harm but also the entire campus community (Drum \& Denmark, 2012; Jed Foundation \& Education Development Center, 2011; Jodoin \& Robertson, 2013). “The healthpromoting contributions of the student's environment must be strengthened...success is no longer measured exclusively in lives saved but also in improving the health status of the student population and in reducing the prevalence of negative events" (Drum \& Denmark, 2012, p. 210).

Just as Astin's input-environment-output (I-E-O) model recognized that retention and persistence are influenced by a student's preparation for college, involvement on campus, housing, etc. (Renn \& Reason, 2013); the social ecological framework recognizes the emotional and physical health of a student is influenced by personal decisions, peer influences, relationships with faculty/staff, campus culture, campus policies as well as local, state and federal policies (DeJong, 2009; DeJong \& Langford, 200Jed Foundation \& Education Development Center, 2011; Jodoin \& Robertson, 2013). The social ecological model provides a framework that is useful for examining policies and practices according to five levels of influence:

- Intrapersonal - strategies that influence the behaviors of a student

- Interpersonal - strategies to increase peer and social support

- Institutional - campus policies, climate and culture 
- Community - availability of support services

- Public Policy - laws that affect student emotional and physical health, access to services, etc. (DeJong, 2009; DeJong \& Langford, 2002, Jed Foundation \& Education Development Center, 2011; Jodoin \& Robertson, 2013)

The differences between an organization and institution are important to understand...A university, as an institution, has an internal culture of norms and socialization procedures... Organizations within the university (such as athletic teams, residence halls, and living-learning communities) conform in various ways to these institutional norms. (Jodoin \& Robertson, 2013, p.18).

According to Jodoin \& Robertson (2013) utilizing this approach allows for strategic analysis of the problem, identification of existing programs/policies and gap analysis to lead to new policy/program development. The social ecological framework invites consideration of how initiatives at one level are enhanced or negated by policies/programs operating at another level of influence as well as reinforcing the idea that mental health issues involve the entire campus not just the counseling center (DeJong, 2009; DeJong \& Langford, 200Jed Foundation \& Education Development Center, 2011; Jodoin \& Robertson, 2013).

\section{Intrapersonal}

This level of influence is concerned with strategies that affect the actions of a person (Jed Foundation \& Education Development Center, 2011; Jodoin \& Robertson, 2013). Policies and programs at this level are focused on developing coping and academic skills, personal growth and making good decisions (Jed \& Clinton Foundations, n.d.; Jed Foundation \& Education Development Center, 2011; Jodoin \& Robertson, 
2013). “Today's college students are rule followers... it comes with a twist. They have to be told the rules...including things like you can't come to class inebriated" (Levine \& Dean, 2012, p. 52).

The traditional age students on a college/university campus will be presented with numerous challenges to overcome as they grow, learn and take responsibility for themselves (Baxter Magolda, 2002; Jensen Arnett, 2007; Levine \& Dean, 2012; Stuart, 2012). Some have termed the development that occurs from the ages of $18-25$ as emerging adulthood (Jensen Arnett, 2007; Stuart, 2012). Understanding this developmental period allows colleges/universities to realize that many students will need assistance with the transition to higher education. This help includes problem solving, understanding finances and navigating an unstructured environment (Jensen Arnett, 2007; Stuart, 2012). Many institutions are building these skills into first year experience courses/programs to facilitate the transition to college and increase retention and persistence (Drum \& Denmark, 2012). According to Stewart (2012):

[Students] need to be taught that they have to engage actively and intentionally in their education. Open institutional approaches recognize both the transitional nature of this highly vulnerable time of life and the need for programs that can nurture their students and provide the emotional support that all of them—not just those with specific mental health problems need in order to survive. (p. 361). The freedoms connected with being a traditional college student are not always associated with positive behaviors. Often this developmental period is marked with feeling invincible and students may engage in excessive drinking, experiment with drugs and/or other dicey behaviors (Jensen Arnett, 2007). Therefore it is not surprising that this 
is also a time of high anxiety (Jensen Arnett, 2007; Stuart, 2012). By understanding this, institutions can change from viewing anxiety as a sign of crisis to recognizing it as a process of normal development and plan for it. As Reynolds (2009 \& 2013) points out most student affairs professionals report helping students with anxiety are common occurrence but one that entails more on-the-job training. Being proactive means students affairs preparation programs and professional development for faculty and staff would address the knowledge and skills to support students as they complete the developmental tasks associated with taking responsibility for self and becoming an adult (Baxter Magolda, 2002; Reynolds, 2009 \& 2013; Stuart, 2012).

Another population on campus that must be considered is veterans. The term veteran in higher education encompasses retired and former military, those currently serving in the National Guard and on active duty (Renn \& Reason, 2013). Students that are currently serving may face class disruption issues for deployments and drill/training exercises (Renn \& Reason, 2013). Short-term disruptions can usually be accommodated by faculty working with the veterans assistance office (Renn \& Reason, 2013). Academic disruptions due to deployments of longer duration are best handled with expedited reenrollment and military credit transfer policies (Renn \& Reason, 2013).

College/universities need to be aware of and plan for the stress that deployments and reenrollment can have on veterans (Renn \& Reason, 2013). Providing a veterans support office to assist with registration, credit transfer, financial aid, counseling is a good start (Renn \& Reason, 2013). This office can also maintain contact with students who deploy which will make reenrollment less stressful (Livingston, Scott, Havice \& Cawthon, 2012). Peer support is important to this community and veterans turn to each 
other for support (Livingston et al., 2012). A support office can facilitate safe space for veteran to talk about experiences and issues in transitioning to the student role (Livingston et al., 2012). Another support for veterans is faculty and staff who have served. The support office can help link student veterans with faculty and staff who understand and can provide mentorship and support (Livingston et al., 2012). By knowing who is on campus and in the classrooms, "faculty, staff and scholars can better understand and predict how various groups of students may take advantage of learning opportunities or behave when encountering or experiencing different aspects of college life, inside and outside the classroom" (Hu, Katherine \& Kuh, 2011, p. 6).

\section{Curriculum Infusion}

Curriculum infusion has been used as a prevention strategy for substance abuse and is an example of an intrapersonal level initiative (Mitchell et al., 2012). Curriculum infusion in context of this dissertation is defined as activities and assignments that engage students to develop academic, coping and decision making skills while focusing on course content (Mitchell et al., 2012). At Emory the Graduate School has used academic programming to bring together students and faculty to promote wellness and self-care as well as developing a suicide prevention class (Kaslow et al., 2012). Emory has also had an "interdisciplinary learning experience that combined academic and community internship experience linked to residence life that targeted addiction and depression, key risk factors for suicide" (Kaslow et al., 2012, p. 129).

University of Buffalo engaged in a partnership between the counseling center and faculty in the departments of visual studies, theater and dance, communications and the interdisciplinary minor in wellness and health (Mitchell et al., 2012). Class activities 
included dramatic arts and dance performances, developing marketing campaigns and awareness programs and a writing contest focused on mental health issues (Mitchell et al., 2012). These efforts resulted in direct contact with 400 students who had the opportunity to learn about services available on campus and engage with counseling and health center staff outside of a clinical setting (Mitchell et al., 2012). Since 2005, Georgetown University has had a similar program to infuse health and wellness in the curriculum (Douce \& Keeling, 2014). Through activities such as using blood alcohol levels in math classes, the program has infused wellness in 225 courses and reached 7,500 students (Douce \& Keeling, 2014).

The goal of the intrapersonal level is to have an effect with a greater number of students. Faculty and staff working with students need to remember the power that comes from asking a student about his/her story (Hight \& Holmes, 2013; Lancaster \& Waryold, 2008). Asking about the story makes a connection; it allows a personal connection so the student feels he/she is more than just a number on campus (Hight \& Holmes, 2013). At the intrapersonal level, "the burden of engagement lies heavily on the institution and very lightly on the students-who must act to avoid benefiting rather than act in order to benefit" (Drum \& Denmark, 2012, p. 215). Wider engagement also allows more campus entities to become involved and implement programing, which facilitates creativity and sustainability (Drum \& Denmark, 2012).

\section{Interpersonal}

Traditional age college students are more likely to turn to friends for advice with a mental health issue than family or other adults (Novotney, 2014). "Suicidal students may feel that simply telling others about their suicidal distress is sufficient, as $52 \%$ reported 
telling the first person was helpful or very helpful" (Swanbrow Becker \& Drum, 2015, p. 77). Strategies at the interpersonal level are designed to reduce isolation and increase peer support for students.

Peers in general and students in peer educator roles in particular play a huge role in supporting students who may be a threat to self (Swanbrow Becker \& Drum, 2015). The origins of peer educators can be traced back to Harvard and Boston Universities (Ganser \& Kennedy, 2012). In the late 1880's, new students were often engaged in class discussions lead by older students working with faculty (Ganser \& Kennedy, 2012). Today peer educators are resident assistants (RAs), orientation leaders, assist in academic courses and provide co-curricular programming on a wide range of topics (Daddona, 2011; Ganser \& Kennedy, 2012). Given the numerous ways that peer educators are utilized on college campuses today, they are an important resource for supporting, providing resources and intervening with students. For example, the "University of Wisconsin [utilizes] peer leaders who are specially trained to provide programmatic resources and emotional support for LGBT students" (Ganser \& Kennedy, 2012, p. 25). These peer leaders can empathize with the student's experiences and provide authenticity and validation that may be missing in interactions with campus professionals (Ganser \& Kennedy, 2012).

RAs are certainly on the front lines in providing support and intervention in residence halls (Daddona, 2011; Ganser \& Kennedy, 2012). In recent years there has been an effort to incorporate evidenced based training for RAs on alcohol, drug and mental health issues (Thombs, Gonzalez, Osborn, Rossheim \& Suzuki, 2015). Gatekeeper training is based on the premise that those most likely to encounter students 
at risk of self-harm should have the knowledge to recognize a problem and intervene appropriately (Swanbrow Becker \& Drum, 2015; Taub et al., 2013). Peer Hero is another approach that utilizes video scenarios to facilitate discussions about how to intervene with students in crisis (Thombs et al., 2015). RAs are more likely to make referrals when they have accurate information and a personal connection so it is important to involve staff from the counseling center and other offices that provide student support in training (Taub \& Servanty-Seib, 2010; Taub et al., 2013; Thombs et al., 2015).

The University of Illinois offers an online training program to all students, faculty, staff and parents. The goal is to recognize a student who may engage in selfharm, support the student and get him/her assistance (University of Illinois Kognito Training, n.d.). The training uses interactive video to allow the participant to decide what to say and/or do when engaging with a student/peer who is experiencing distress (University of Illinois Kognito Training, n.d.). Approximately 800-900 campus community members have taken the online training (McNicholl, 2014). The University of Illinois counseling center has oversight for the training and the goal is to make the training mandatory for all new students and faculty/staff (McNicholl, 2014).

Training for campus constituencies in how to identify students at risk of self-harm and connect him/her to services is needed and necessary. "Among students who disclosed their suicidal ideation to others, only $58 \%$ of undergraduates and $50 \%$ of graduate students were advised by the first person they told to seek professional help" (Drum, Brownson, Burton, Denmark \& Smith, 2009, p. 218). A student was more likely to be told to get help if he/she disclosed to a professor or family (Drum et al., 2009). According to Gruttadaro and Crudo (2012), "the college educates faculty staff and students on 
mental health was among the top five reasons that at-risk students believe their college is supportive" (p. 19). Providing training, identifying distressed students and linking them to services are characteristics of a caring institutional culture.

\section{Institutional}

The institutional level of influence is focused on institutional planning, policies and processes that create/inhibit a supportive campus learning environment (DeJong, 2009; DeJong \& Langford, 2002, Jed Foundation \& Education Development Center, 2011; Jodoin \& Robertson, 2013). "Having comprehensive and clear policies around health, mental health and substance misuse are important ingredients in prevention. Policies, systems, and strategic planning demonstrate that the school takes these issues seriously and addresses them in a thoughtful, pragmatic, and formal way" (Jed \& Clinton Foundations, n.d., p. 4).

Institutions should recognize the impact of policies and services that are proactive and caring. Prospective students and families are asking about campus counseling services, services that are available in the surrounding community, disability accommodations, and parental notification (Bishop, 2010). According to Meunier \& Wolf (2006) "an institution's ability to address student mental health needs is becoming a factor in college application decisions" (p. 44). The campus counseling center may also play a role in retention. According to Eisenburg, Golberstein and Hunt (2009) depression is negatively associated with GPA and an $8 \%$ increase in the likelihood of leaving college. However, students seen at college counseling centers have a $7 \%$ increase in first year retention compared to the general student body (Bishop, 2010). Eisenberg et al. (2009) also found that an online mental health screening program would more than pay 
for itself by the number of students identified with depression/anxiety who seek help and stay in school. This estimate was based on just $7 \%$ of the student body seeking help (Eisenberg et al., 2009). Institutional cost is a frequently cited barrier to achieving to the preferred counselor to student ratio of 1:1,500 (Bishop, 2010; Fox \& Savage, 2009). However an "appropriately staffed counseling center can be a major contributor to an institution's ability to sustain tuition revenues and contain recruitment costs" (Bishop, 2010, p. 253).

Institutions need to review policies to determine if they are punitive to students who seek help for mental illness and/or make it hard to get the needed accommodations to persist to graduation (Bazelon Center for Mental Health Policy and the Law, 2007; Center for Mental Health Services, Substance Abuse and Mental Health Services Administration, 2007; Salzer, 2012; Stuart, 2012). "More than 45\% of students who stopped attending for mental health related reasons did not receive accommodations" (Gruttadaro \& Crudo, 2012, p. 8). Promoting awareness of and assistance with the process for receiving accommodations during admissions events and orientation can overcome barriers student often face when seeking assistance (Gruttadaro \& Crudo, 2012,). Western Illinois University's syllabus policy includes the following information: In accordance with University policy and the Americans with Disabilities Act (ADA), academic accommodations may be made for any student who notifies the instructor of the need for an accommodation. For the instructor to provide the proper accommodation(s) you must obtain documentation of the need for an accommodation through Disability Resource Center (DRC) and provide it to the instructor. It is imperative that you take the initiative to bring such needs to the 
instructor's attention, as he/she is not legally permitted to inquire about such particular needs of students. (wiu.edu/policies/syllabus.php).

Campus disability resource centers can work with students on how to discuss accommodations with professors as well as work with faculty on what procedures to follow when a student presents documentation of accommodations (Gruttadaro \& Crudo, 2012,).

Removing the means for students to inflict self-harm is an important policy consideration. Restricting access to roofs and other protective barriers to prevent fall and jumping, break-away closet rods, disposal program for prescription drugs would be examples of means restrictions (Drum and Denmark, 2012; Jed \& Clinton Foundations, n.d.). Guns on campus is listed as number six of the top ten policy concerns for 2015 (American Association of State Colleges and Universities, 2015).

The number of states in which lawmakers have stripped institutions' ability to ban guns on campus now stands at seven...Currently, 20 states ban concealed weapons on campus, while 23 states allow individual public institutions to set their own concealed weapons policy. (American Association of State Colleges and Universities, 2015, p. 4).

The prohibition of firearms on campus is a major reason cited for the $50 \%$ difference in the suicide rate between college students and peers who do not attend (Drum and Denmark, 2012). As gun laws change it will be important for college/universities to increase efforts to identify and connect students at-risk for self-harm to resources and help. 
University of Illinois created a campus policy for suicide. The policy reads:

The University of Illinois expects and encourages students to maintain a reasonable concern for their own self-welfare. One of the times the University formally requires that such concern be maintained is in the area of suicide. In the event that the University is presented with a credible report that a student has threatened or attempted suicide, engaged in efforts to prepare to commit suicide or expressed a preoccupation with suicide, that student will be required to attend four sessions of professional assessment. The purpose of this assessment is to provide the student with resources to adhere to this standard in the future and to monitor the student's willingness and ability to adhere to this standard. (University of Illinois Suicide Policy, n.d., n.p.).

The University of Illinois began instituting a suicide policy in 1984 as part of a suicide prevention program (Joffee, 2009). The program outcomes include a $45 \%$ decrease in completed suicides and only one student who was medically withdrawn from campus (Joffee, 2009).

Learning outcomes are not just tied to the classroom. Learning involves the whole student and the whole campus (Douce \& Keeling, 2014). Recognizing the bond between learning and mental health concerns means that college /universities need to look strategically at institutional planning, policies and processes that create/inhibit a supportive campus learning environment (DeJong, 2009; DeJong \& Langford, 2002, Jed Foundation \& Education Development Center, 2011; Jodoin \& Robertson, 2013). 


\section{Community}

Students venture off campus for a variety of reasons. The community surrounding campus can play an important role in providing services and support that influence the health and wellness of students (DeJong, 2009; DeJong \& Langford, 2002, Jed Foundation \& Education Development Center, 2011; Jodoin \& Robertson, 2013). Emory University has developed a campus community coalition for suicide prevention (Kaslow et al., 2012). Community partners include agencies working in medicine, public health, crisis services, community government, law enforcement and concerned citizens (Kaslow et al., 2012). The coalition allows Emory to have open communication and partnerships with the community and to direct more resources (time, talent, dollars) to suicide prevention than if the institution worked alone (Kaslow et al., 2012). The coalition works to ensure that service providers on and off campus are linked together and understand policies for coordination of care and awareness campaigns are collaborative and messages on campus are reinforced in the community (Kaslow et al., 2012).

Not all the entities that are needed to provide services and treatment for students will be available on campus. Memoranda of understanding (MOUs) are useful to detail relationships with inpatient and outpatient treatment facilities regarding sharing of information, costs, transportation and follow-up care (Jodoin \& Robertson, 2013). Programs and policies at the community level of influence are designed to have town and gown work together to positively affect students' growth and behavior (Jodoin \& Robertson, 2013). 


\section{Public Policy}

Elected officials at the federal, state and local levels enact policy to address concerns or solve perceived problems on college campuses. Incidents that happen on college campuses generate public interest and concern. In short these incidents serve as focusing events.

A focusing event is an event that is sudden; relatively uncommon; can be reasonably defined as harmful or revealing the possibility of potentially greater future harms; has harms that are concentrated in a particular geographical area or community of interest; and that is known to policy makers and the public simultaneously. (Birlkland 1998, p. 54).

Although it may be common sense that legislators will respond to what they see as constituent concerns, does this result in good policy? Some of the focusing events are "low-probability/high-consequence events" that do not need to be solved (Birkland, 2006). Sometimes federal and state legislation may result in policies that inhibit practices that promote a supportive caring environment and other times the policies may provide new opportunities. Good policy results from knowing when there is a real problem that needs a solution and a Band-Aid is a term often used when there is no real problem but a solution is proposed or a solution that does little to fix the problem (Birkland, 2006).

Chapter 5 detailed the changes to Title II legislation and it's provisions when students are a threat. This section contains additional examples of public policies that have bearing on campuses actions regarding student well-being. 


\section{Garrett Lee Smith Memorial Act}

The Garrett Lee Smith Memorial Act, named for the son of Senator Gordon Smith who committed suicide, was signed into law in October of 2004 (Goldston et al., 2010). Among the provisions in the legislation was the creation of the Campus Suicide Prevention program which make grants available to colleges/universities to provide services for mental and behavioral health problems and is administered by the Substance Abuse and Mental Health Services Administration (SAMHSA) (APA, n.d.; Goldston et al., 2010; SAMHSA, 2015). To apply for a grant college/universities must match the funding provided by grant dollar for dollar with non-federal funds (Goldston et al., 2010; SAMHSA, 2015). In 2015, 20 three-year grants were available and the award amount was $\$ 102,000$ annually (SAMHSA, 2015). Funds received may not be used for therapy, medication or medical residency training programs (APA, n.d; SAMHSA, 2015).

In the ten years that these grants have been available, information has been disseminated on cultural factors of suicide risk and prevention, campus environmental factors related to risk and prevention and barriers to help-seeking among college students (Goldston et al., 2010). It should be noted that the grant projects under this program are service based not research based (Goldston et al., 2010). The goal of the program is to "assist colleges and universities to have a campus free from the tragedy of suicide" (SAMHSA, 2015, n.p.). Although a worthy goal, attempts to increase funding through reauthorization have failed, thus the program has the potential to be good policy but currently is a band-aid. 


\section{Policy in Response to Campus Shooting Incidents}

The shootings at Virginia Tech, Northern Illinois University and Louisiana State University occurring within a very short time of each other generated increased attention on campus mental health issues, campus violence and caused society to ask how events like this continue to happen. At the federal level legislation included created the National Center for Campus Public Safety, modified FERPA and HIPAA to provide clarity regarding the sharing of information, and added provisions regarding campus emergency planning to existing higher education legislation (Sokolow \& Hughes, 2008).

Following the incidents, some states set up mandated college/university task forces to study campus safety, required campuses to develop safety plans, required joint training and agreements between campus security/law enforcement and community law enforcement, required campus threat assessment teams and mandated that institutions provide training for students, faculty and staff regarding campus safety and recognizing disturbing behavior (Connecticut S.B. 467, 2008; Illinois S.B. 2691, 2008; Rasmussen \& Johnson, 2008; Virginia H.B. 1449, 2008; Washington S.B. 6328, 2008). Forms of coercion ranged from "let's study this" to a complete change of the rules and unfunded mandates. In Illinois, the legislature learned what was needed from experience. By enacting the Campus Security Enhancement Act of 2008:

Illinois became the first state in the nation to require all colleges in the state to develop and exercise an all-hazards emergency response plan and an interdisciplinary and multi-jurisdictional campus violence plan...The Act also requires the development and implementation of a campus violence prevention committee 
and campus threat assessment team for each higher education institution. (Burke, 2010, p. 13)

Although active shooter events on college campuses are rare, their legacies have been changes to the way colleges handle disturbing students, faculty and staff. For example the legacy of the 1966 University of Texas bell tower shooting was to implement on campus counseling services (Helibrun, et al. 2009). The increased focus on threat assessment teams and campus intervention teams (discussed further in the Multiple levels of influence section) is the legacy from the Virginia Tech shooting (Cornell, 2010; Helibrun, et al. 2009).

\section{Parental Notification Legislation}

Both Virginia and Illinois legislatures introduced bills in early 2015 regarding parental notification when dependent students received mental health treatment (Illinois H.B. 3599, 2015; Virginia S.B. 1122, 2015). Although Virginia has legislation regarding parental notification when student receiving treatment demonstrates a likelihood of being a threat to self or others (Koenig, 2015; Virginia S.B. 1122, 2015), the Senate caused a stir among public higher education administrators by proposing the following addition to the required notification:

The parent of a dependent student when the institution obtains information outside the mental health treatment setting that such student is exhibiting suicidal tendencies if knowledge of the information is necessary to protect the health or safety of the student or other individuals. (Virginia S.B. 1122, 2015, subsection C:2) 
Although this clause was not included in the signed legislation (Virginia Chapter $716,2015)$, this is the second time that such legislation was proposed. The bills sponsors have been advocating for the legislation because of Virginia Tech student, Daniel Kim, who committed suicide in 2007 (Koenig, 2015). A friend of Kim reported the suicidal behavior to Virginia Tech staff but the information was never reported to parents or the counseling center (Koenig, 2015). Opponents of the legislation feel that it was written broadly and would add another barrier to college students seeking help (Koenig, 2015).

The pending legislation in Illinois would allow a college student to fill out a form indicating a person(s) to contact if a physician or counselor determines he/she is a threat to self or others (Illinois H.B. 3599, 2015). This bill also came about because parents of a student who committed suicide suggested the idea (Leitch, 2015). However there is not the same level of mandatory reporting in this legislation as what was proposed in Virginia. The student has the option to designate a person or not (Illinois H.B. 3599, 2015).

Legislative mandates can be both threats and opportunities for colleges and universities. The courts and legislators are sending messages that colleges must proactively address mental health issues on campus (Grasgreen 2014; Lannon and Sanghavi 2011; Lewis, Schuster and Sokolow 2012; Mahoney, 2005). If higher education does not act, politicians will.

\section{Multiple Levels of Influence: Campus Intervention Teams}

Campus intervention teams can be useful in more than threat assessment situations. Sokolow and Lewis (2009) believe that the team's ability "for longitudinal tracking of student behaviors over time... and ability to see trends in behavior, both 
individually collectively" mean that it is well suited to manage behavioral interventions on campus. Penven and Janosik (2012) believe that campus intervention teams have a huge role to play in intervention with suicidal students. A recent survey by the Association for Student Conduct Administration (2014) found that over $80 \%$ of responding colleges/universities would refer a student who was a threat to self to the campus intervention team. Given the utility and in some states the legislative mandates, it is understandable why over $90 \%$ of colleges/universities are either implementing or have implemented behavioral intervention and/or threat assessment teams (Van Brunt \& Lewis, 2014). This section reviews best practices for intervention teams.

\section{What Do We Call the Team?}

Campus intervention teams function under many names such as behavioral intervention teams, campus response teams, threat assessment teams and various other acronyms (Eells \& Rockland-Miller, 2010; Shang \& Barkis, 2009; Sokolow \& Lewis, 2009). The name of the team should reflect the purpose (Eells \& Rockland-Miller, 2010; Sokolow \& Lewis, 2009). However there is caution when using threat assessment in the name. According to Eells and Rockland-Miller (2010), "the words threat assessment may cause adverse reactions on campus and the teams may not actually engage in the practice of threat assessment" (p. 11). Sokolow and Lewis (2009) feel that colleges should "choose a name that coveys your team is about supportive and caring intervention" (p. 5).

\section{Team Mission}

Some college campuses may have several teams with very focused missions of crisis management, threat assessment and behavioral intervention (Eells \& RocklandMiller, 2010; Pavela, 2008). However the majority of institutions have one, or at most 
two teams, and will need to decide if their function is primarily crisis response, threat assessment or supporting the campus community (Eells \& Rockland-Miller, 2010; Sokolow \& Lewis, 2009). Threat assessment teams will be focused on "early identification of situations that are likely to pose a risk, providing a baseline against which to measure changes in the situation, and facilitating development and implementation of interventions to increase likelihood of a safe resolution" (Pavela, 2008 , p. 2). Intervening early to prevent behavior from reaching a crisis stage is what the teams are designed to do (Sokolow \& Lewis, 2009). It is important to remember that not all students who exhibit behavior that is concerning will also be a threat to themselves or others (Helibrun, Dvoskin \& Helibrun, 2009).

Another decision that affects the mission is whether the scope of team will address only students or include faculty and staff (Eells \& Rockland-Miller, 2010; Sokolow \& Lewis, 2009). This may not be an either or type question. A team may start out focusing on students and expand over time to include faculty and staff (Sokolow \& Lewis, 2009). One team focusing on students, faculty and staff will have some adjustments to make in team membership and record keeping but it can be implemented effectively (Sokolow \& Lewis, 2009).

\section{Team Membership}

To be effective teams must be interdisciplinary (Dunkle et al., 2008 et al., 2008; Eells \& Rockland-Miller, 2010; Fox \& Savage, 2009; Helibrun et al., 2009; Keller, Hughes \& Hertz, 2011; Pavela, 2008; Penven \& Janosik, 2012; Piet DeLaTorre, 2011). Some state legislatures, such as Virginia and Illinois, mandated institutions of higher education not only have threat assessment teams but who should serve on them such as 
representatives from law enforcement, human resources, student services, counseling services and legal counsel (Penven \& Janosik, 2012). There is common agreement in the literature that teams should have at minimum law enforcement, student affairs, legal counsel and mental health services (Dunkle et al., 2008; Eells and Rockland-Miller 2010; Fox and Savage 2009; Helibrun et al., 2009; Keller et al., 2011; Pavela, 2008; Penven \& Janosik, 2012; Piet DeLaTorre, 2011). Others to consider for membership include faculty, human resources, public relations and disability services (Dunkle et al., 2008; Eells \& Rockland-Miller, 2010; Fox \& Savage, 2009; Keller et al., 2011; Pavela, 2008; Penven \& Janosik, 2012; Piet DeLaTorre 2011). Other campus and community professionals can be consulted as needed (Dunkle et al., 2008; Fox \& Savage, 2009; Keller et al., 2011; Penven \& Janosik, 2012; Sokolow \& Lewis, 2009).

Another facet of membership to consider is who will lead the team? The majority opinion expressed in the literature is that an upper level student affairs administrator should lead the team (Dunkle et al., 2008; Eells \& Rockland-Miller, 2010; Sandeen, 2009). Rationale includes that this person would not be bound by client confidentiality, would have power to issue interim suspension and/or medical leave interventions and understands the dynamic between student privacy/due process and campus community concerns (Dunkle et al., 2008; Eells \& Rockland-Miller, 2010; Sandeen, 2009). There are teams that are led by the chief of campus safety (Pavela, 2008; Penven \& Janosi, 2012). These teams may be very focused on incident response and the chiefs training and experience is valuable in the leadership role (Pavela, 2008). There are also behavioral intervention teams that are led by counseling service providers, however the concerns of 
client confidentiality must be addressed and planned for (Eells \& Rockland-Miller, 2010; Pavela, 2008).

\section{Initial and Follow-Up Assessment}

The team needs to have an initial assessment protocol to be able to determine if a student poses a risk to him/herself or others (Dunkle et al., 2008; Helibrun et al., 2009; Sokolow and Lewis 2009). The initial assess should take into account current and prior behavior, cultural considerations, environmental factors (Pavela 2008; Shang \& Barkis 2009). This initial assessment is key for determining the appropriate intervention plan (Dunkle et al., 2008; Penven \& Janosik, 2012).

Sokolow and Lewis (2009) are firm that follow-up mandated assessment for an identified student of concern is best practice. Penven and Janosik (2012) feel that mandated assessment may address allegations of negligence should the student harm him/herself. There are mental health providers that feel to mandate assessment creates an artificial environment and skews the results (Sokolow \& Lewis, 2009). A policy should clearly articulate the reasons a mandated assessment can be imposed, requirements for who can conduct the assessment (college counseling center, licensed professional in the community, etc.), what sanctions may be imposed if the assessment is not completed and sharing results of the assessment with the team (Penven \& Janosik, 2012; Sokolow \& Lewis, 2009).

\section{Interventions}

Many colleges use behavioral contracts to educate about disturbing behaviors and as a means to maintain contact and follow-up with students of concern. According to Penven and Janosik (2012) there is very little evidence that behavioral contracts are 
effective. Behavioral contracts will increase institutional liability should a student on a contract harm him/herself or others (Penven \& Janosik, 2012).

Separating the student from campus can be completed voluntary or if the student is a threat to others through a mandatory leave. Similar to mandated assessments the college should have a clear policy for a leave of absence (Dunkle et al., 2008; Penven \& Janosik, 2012). The policy should cover reasons why a voluntary leave will be granted, conditions that warrant a mandatory leave, and conditions that must be met for the student to return to campus (Dunkle et al., 2008; Penven \& Janosik, 2012). Involuntary leave was discussed in depth in chapter five.

\section{Interaction with Campus Community}

For intervention to be truly effective, the campus needs to be educated about risk management, intervention teams and buy into the concept that it takes everyone to create a caring campus (Eells \& Rockland-Miller, 2010; Helibrun et al., 2009; Sokolow \& Lewis, 2009). Team members need to be proactive to create a culture of reporting (Sokolow \& Lewis, 2009). People give us warnings to violent actions. "These clues, signs, and concerns are our best chance to head off violence before it occurs. If we can empower cultures of reporting on our campuses, friends, colleagues, family members, professors, sorority sisters, roommates, RAs can share what they know. But they need to know who to tell... what to report" (Sokolow \& Lewis, 2009, p. 2). The team should make presentations about what to report and who to report it to, they should also educate the community about how the information is handled and that reporting is allowable under FERPA (Dunkle et al., 2008; Fox \& Savage, 2009; Sokolow \& Lewis, 2009). The education and messages provided to the campus community should communicate that 
these strategies are about caring for one another and not fear that an incident will happen (Fox \& Savage, 2009).

\section{Risk Management}

It is important to view the intervention team as one part of an over all risk management program (Sokolow \& Lewis, 2009). Although intervention teams respond to and intervene in more then active shooter situations, they do not eliminate the need for notification systems, emergency plans and drills, etc. (Sokolow \& Lewis, 2009). However, the overall risk management plan should take into account how and where elements interact with each other and overlap (Sokolow \& Lewis, 2009).

\section{"Minding the Gap"}

Sokolow and Lewis (2009) use the phrase "minding the gap" to emphasize the need for long tern follow-up and awareness. A student dropping from the radar may be good that their behavior is no longer concerning or it may indicate a problematic change and it is incumbent upon the team to know what is occurring (Sokolow \& Lewis, 2009). This follow-up can be implemented through a case management approach either by each member of the team carrying a certain number of cases or a designated person in the institution serving as the case manager for follow-up (Dunkle et al., 2008; Eells \& Rockland-Miller, 2010; Penven \& Janosik, 2012).

Campus intervention teams model the social ecological approach. The team assesses an at-risk student in his/her environment and takes into account emotional development, support systems and health status (Pavela 2008; Shang \& Barkis 2009). The plan is determined based on the individualized assessment and with the goal of supporting the student rather than dismissing him/her (Dunkle et al., 2008; Penven \& 
Janosik, 2012).

\section{Reframing Mental Health on Campus}

Many college/university policies and practices are based on person-focused or medical model view of mental health (Drum et al., 2009; Drum \& Denmark, 2012). This paradigm puts the counseling center and/or health clinic at center of intervention with the student (Drum et al., 2009; Drum \& Denmark, 2012). "Difficulties in developing appropriate institutional policies may be aggravated by the narrow scope of the individual-focused paradigm...with its exclusive reliance on identifying and either treating or removing students" (Drum et al., 2009, p. 214). 73\% of students with mental health issues have experienced a crisis in college and 35\% report that their colleges were not aware (Gruttadaro \& Crudo, 2012). Clearly the person-focused model has some deficits when it comes to identifying students. According to one student "the school in which I was medically dismissed from did not respond well. They were too afraid to address the issue at hand; they just sent me away" (Gruttadaro \& Crudo, 2012). One in four college students are diagnosed or treated for a mental health issue each year (Gruttadaro \& Crudo, 2012), colleges/universities need to change paradigms in order to serve students.

Scott (2008) talks about the roles of universities as creator, curator, and critic. Those roles are apt to the discussion of reframing mental health on college/university campuses. With advances in treatment, many more students with mental health issues are able to attend college than in the past (Dunkle, 2009; Massie, 2010; Meunier \& Wolf, 2006; Watkins, Hunt, \& Eisenberg, 2011) as well as taking psychotropic medications (Castillo \& Schwartz, 2013; MacKean, 2011). The advances in treatment and medications 
are due to research most likely conducted at a university medical center, which is the creator role (Scott, 2008).

The curator role may be thought of as a chronicle of history (Scott, 2008). Looking back on the writings of student affairs professionals serves as a reminder that mental health issues are not new to college campuses. Philip Tripp wrote in 1968:

We have yet to deal with the area of teaching people generally to understand their feelings. Our society has been disposed against people admitting they have any feelings. Here is a zone where we must be pioneers and the precursors and the showers of the way. (Tripp, 1968, p. 283)

Scott (2008) speaks of the critic role as "universities must hold up a mirror as well as a spotlight" (p. 5), meaning higher education must own the failures as well as the triumphs. In the institutional policies and practices surrounding mental health in general and students who are a threat to self in particular, there are certainly failures and triumphs. However the roles of curator, creator and critic favorably positions colleges/universities to learn from the failures and design a better way to move forward (Scott, 2008).

Moving forward entails a paradigm shift from a medical or person-focused model to a more holistic approach that focuses on the health and wellness of the campus (Drum et al., 2009; Drum \& Denmark, 2012). It is an approach the directly links physical and mental health with learning and academic success (Douce and Keeling, 2014). It forces colleges/universities to make mental health a strategic issue and engage campus and community partners. "Universities are untapped natural laboratories for innovative programs to prevent suicide. Instead of lagging behind they have the potential to lead the 
nation, saving not only the lives of their own students but of Americans in general" (Joffe, 2008, p. 101). Colleges/Universities have many policies and programs in place, such as campus intervention teams, crisis support staff, peer leaders and academic personnel and support staff. Reframing mental health allows an institution to build upon existing resources and close gaps to support the health and learning of the entire campus community (Douce and Keeling, 2014; Drum et al., 2009; Drum \& Denmark, 2012). 


\section{CHAPTER VII}

\section{TELLING THE STORY}

As described in chapter three, this dissertation is an integrated policy analysis with the goal of understanding the relationship between the law and institutional practices regarding college students who demonstrate a threat to self. In the preceding chapters an investigation was conducted to understand (i) how the courts view college/university duty when a student is a threat to self; (ii) how the federal government, as evidenced by legislation, believes colleges/universities should proceed when a student is a threat to self and (iii) if college/university policies and practices are aligned with the courts and federal legislation.

According to Bardach's (2012) steps for policy analysis, the investigation covered steps “ (1) define the problem; (2) assemble some evidence; (3) construct the alternatives; (4) select the criteria and (5) project the outcomes" (p. xvi). The remaining steps "(6) confront the trade-offs; (7) decide and (8) tell the story" (p. xvi) are the intent of this chapter. According to First et al. (2015) telling the story is a "flippant way to remind us to communicate effectively the results of the study to all the relevant parties but communicating in an interesting and story-like may be exactly what we need to do if we wish to influence policy" (p. 149). 


\section{Current Jurisprudence Regarding College/University Liability When a Student is a Threat to Self}

It is an accepted legal principle that there is no duty to help another person unless there is a special relationship. Colleges/universities may assume a duty through existence of a special relationship, position as a landowner and/or "by campus police who undertake to render services for the protection of students" (Sokolow et al., 2008, p. 320). Historically the courts have viewed suicide as a self-imposed act and only recognized liability if defendant actions lead to the suicide or in rare instances there was duty to prevent the suicide (Alexander \& Alexander, 2011; Lake, 2013). This view of suicide as an intervening cause is espoused in Bogust v. Iverson (1960) the first published appellate case dealing with college student suicide (Alexander \& Alexander, 2011; Fossey \& Moore, 2010). The superseding-intervening act doctrine was upheld in Jain v. State of Iowa (2000) relied on the to find that the University of Iowa was not liable.

The courts in Schieszler v. Ferrum College (2000) and Shin v. Massachusetts Institute of Technology (2005) cast doubt on the ability of college/universities to rely on superseding-intervening act doctrine when they ruled that these cases could proceed to trial. However colleges/universities also over reacted to this ruling by interpreting it to mean any knowledge of behavior indicating self-harm automatically implied a special relationship. As discussed in chapter four, Schieszler and Shin did not go to trial and the applicability is a very narrow situation of knowledge that a student is at risk of imminent self-harm and not taking action will result in injury or death (Lapp, 2010; Pavela, 2012). Furthermore, no court has followed the Schieszler and Shin ruling (Fossey \& Moore, 2010; Kalchthaler, 2010). 
The court in Bradshaw v. Rawlings (1979) contends "the modern American college is not an insurer of the safety of its students" (p. 138). Bash v. Clark College (2006) essentially agrees noting that the court would weigh the potential harm of injury from drugs with the burden on a college/university to protect a student from that harm. Mahoney v. Allegheny College (2005) offers the most instruction to college/universities: We believe the "University" has a responsibility to adopt prevention programs and protocols regarding students self-inflicted injury and suicide that address risk management from a humanistic and therapeutic as compared to just a liability or risk avoiding perspective... Rather than create an ill-defined duty of due care the University and mental health community have a more realistic duty to make strides toward prevention. (Mahoney, 2005, p. 25)

Colleges/universities need to heed the message in Mahoney that suicide is an intervening event and the fear of litigation should not prevent a college/university from helping its students (Bash, 2006; Lake, 2009 \& 2013; Lapp, 2010; Mahoney, 2005; Pavela, 2012).

\section{Synergy Between the Courts and Changes to Title II}

With the 2010 change to the direct threat standard in Title II of the Americans with Disabilities Act, the federal government is most certainly sending the message that the fear of liability should not prevent a college/university from helping its students (Grasgreen, 2014; Lannon \& Sanghavi, 2011; Lewis, et al., 2012). Most students expressing thoughts of self-harm or suicidal ideation do not go on to actually harm themselves or commit suicide.

Odds that a student with suicidal ideation will actually commit suicide are 1,000 to 1 . Thus policies that impose restrictions on students who manifest suicidal 
ideation will sweep in 999 students who would not commit suicide for every student who will end his or her life...And even if such restrictions were limited to the students who actually attempt suicide, the odds are around 200 to 1 against the school's having acted to prevent a suicidal outcome. (Appelbaum, 2006, p. 915) Yet according to a recent survey, nearly a third of colleges/universities are still utilizing mandatory withdrawal policies to intervene with students who are a threat to self (ASCA, 2014).

The changes in Title II mean that disparate treatment analysis will be used in place of direct threat analysis when a student is a threat to self (Lannon, 2014; Lewis, et al., 2012). In order to comply college/universities need to should review policies to determine if the apply to both students with and without disabilities (Lannon, 2014; Lewis, et al., 2012). The question should be asked is the student transported to the hospital for self-cutting treated the same as the student who is transported to the hospital for consuming too much alcohol (Lannon, 2014; Lewis, et al., 2012)? If the answer is no, the institution needs to examine policies and practices to ensure compliance.

The changes in the law are not meant to make college/universities mental health treatment facilities. However involuntary or mandatory leave should not be the first step. It should only be used after an individualized assessment has been completed and a full examination of the feasibility of other accommodations (Lannon, 2014; Lewis, et al., 2012). The student must also be given the opportunity to be heard, to appeal the decision and be given the criteria to meet for return to the campus (Lannon, 2014; Lewis, et al., 2012). 


\section{Implications for Institutional Policies and Practices When a Student is a Threat to Self}

Colleges/Universities need to make the connection between the physical and mental health and academic success of their students. This involves engaging in strategic planning to understand how initiatives at one level are enhanced or negated by policies/programs operating at another level of influence as well as reinforcing the idea that mental health issues involve the entire campus not just the counseling center (DeJong, 2009; DeJong \& Langford, 200Jed Foundation \& Education Development Center, 2011; Jodoin \& Robertson, 2013). Most institutions already have the practices in place to support students who are a threat to self. Engaging in strategic planning allows the institution to build on its strengths and existing resources as well as illuminate the gaps that exist (Douce \& Keeling, 2014; Drum et al., 2009; Drum \& Denmark, 2012).

Provide training regarding identifying distressed students and linking them to services. Campuses promote cultural competence but there needs to be recognition of the roles of gender and sexual orientation in physical and emotional health. These topics need to be discussed in training for faculty, staff and students but also infused through the curriculum. A student was more likely to get help if he/she spoke with a faculty member but it is known the students speak to peers first (Drum et al., 2009; Novotney, 2014; Swanbrow Becker \& Drum, 2015). Colleges/universities need to infuse wellness through out the campus so that students would have to actively work to avoid messages of selfcare and supporting others (Drum \& Denmark, 2012).

Wider engagement also allows more campus entities to become involved and implement programing, which facilitates creativity and sustainability (Drum \& Denmark, 
2012). Bring together campus and community partners to share ideas and resources (DeJong, 2009; DeJong \& Langford, 2002, Jed Foundation \& Education Development Center, 2011; Jodoin \& Robertson, 2013; Kaslow et al., 2012). Engage internal and external stakeholders in working for legislation the provide opportunities for campuses to improve services for students and to work against federal, state and local government policies that will put barriers in the way of seeking help (Kaslow et al., 2012).

Colleges/universities have more students on campus with anxiety, depression and other mental health concerns (Dunkle, 2009; Massie, 2010; Meunier \& Wolf, 2006; Watkins, Hunt, \& Eisenberg, 2011). Many institutions believe that these students increase campus risk and liability (Appelbaum, 2006; Massie, 2008; Pavela, 2006 \& 2010). According to the courts and legislation, the true increase in risk and liability occurs when colleges/universities do not proactively plan for and support these students (Bash, 2006; Douce \& Keeling, 2014; Drum et al., 2009; Drum \& Denmark, 2012; Lake, 2009 \& 2013; Lannon, 2014; Lapp, 2010; Lewis, et al., 2012; Mahoney, 2005; Pavela, 2012).

\section{Future Research}

A dissertation is only a brief snapshot in time and an attribute of law and policy is that they are dynamic and change is a given. In that vein there are areas of research that will influence the policy story and recommendation presented here. The issue of parental notification bears watching. Currently it is just Illinois and Virginia, however if other states follow a policy study on the state legislation and implications for court rulings regarding negligence if a college/university fails to notify a parent would be warranted. Another area is the increasing presence of firearms on campus. A retrospective policy analysis of the injuries and deaths that occurred on college/university campuses 
that have lost the ability to ban firearms or must allow accesses in certain locations would yield useful information on the link between guns and college suicides (American Association of State Colleges and Universities). This would be significant given prohibition of firearms on campus is a reason cited for the $50 \%$ difference in the suicide rate between college students and peers who do not attend (Drum and Denmark, 2012) and could lead to identification of other protective factors.

More research is needed to understand the relationship between gender and sexual orientation as a trigger for self-harm. This research is also necessary to inform practice for both clinicians and college/university personnel to intervene in a manner that does not cause the student further distress.

When discussing the link between the law and stories, Faber and Sherry (1993) noted that scholarship increases knowledge but that the "best scholarship not only adds to the reader's knowledge directly but inspires further thought beyond the text" (p. 851). The author hopes the reader of this dissertation has been given much to ponder. 


\section{REFERENCES}

Act Concerning Security Protocol at the Constituent Units, Connecticut S. 467. (2008).

Alexander, K. W., \& Alexander, K. (2011). Higher education law: Policy and perspectives. New York, NY: Routledge.

Ali, A., Caplan, P. J., \& Fagnant, R. (2010). Gender stereotypes in diagnostic criteria. In Handbook of gender research in psychology (pp. 91-109). New York, NY: Springer.

American Council on Education. 1949. The student personnel point of view: Revised edition. In Saddlemire, G. L. \& Rentz, A. L. (Eds.), Student affairs-a professions' heritage: Significant articles, authors, issues and documents (pp. 74-87). Alexandria, VA: American College Personnel Association Media Publication.

American Psychological Association (n.d.). Campus suicide prevention program. Retrieved from http://www.apa.org/about/gr/issues/education/campussuicide.aspx.

Americans With Disabilities Act (1991). http://www.ada.gov/reg2.htm

Americans With Disabilities Act (2010). http://www.ada.gov/regs2010/ titleII_2010/ titleII_2010_regulations.htm

Andover, M. S., Primack, J. M., Gibb, B. E., \& Pepper, C. M. (2010). An examination of non-suicidal self-injury in men: Do men differ from women in basic NSSI characteristics?. Archives of Suicide Research, 14(1), 79-88.

Appelbaum, P. S. (2006). Depressed? get out! Dealing with suicidal students on college campuses." Psychiatric Services 57(7), 914-916.

Association for Student Conduct Administration. (2014). Self injurious behavior and institutional protocols. ASCA Report. Retrieved from http://theasca.org.

Baker, K. J. M. (2014, February 11). How colleges flunk mental health. Newsweek Magazine. Retrieved from http://www.newsweek.com/2014/02/14/how-collegesflunk-mental-health-245492.html

Bardach, E. (2005). A practical guide for policy analysis: The eightfold path to more effective problem solving. Washington D.C.: CQ Press. 
Barr, M. J. (2009). Foreword. New Directions for Student Services, 2009(128), 3-4

Bash v Clark College 22 Mass. L. Rep 84; 2006 Mass Super. (2006).

Baxter Magolda, M. B. (2002). Helping students make their way to adulthood. About Campus, January/February(2002), 2-9.

Bazelon Center for Mental Health Policy and the Law. (2007). Supporting students: A model policy for colleges and universities. Retrieved from http://www.bazelon.org/pdf/ SupportingStudents.pdf.

Bickel, R. D. \& Lake, P. F. (1999). The rights and responsibilities of the modern university: Who assumes the risks of college life?. Durham, NC: Carolina Academic Press.

Birkland, T. A. (1998). Focusing events, mobilization, and agenda setting. Journal of Public Policy 18(1), 53-74.

Birkland, T. A. (2006). Lessons of disaster: Policy change after catastrophic events. Washington, DC: Georgetown University Press.

Blaesser, W. W. (1949). The future of student personnel work in higher education." In Saddlemire, G. L. \& Rentz, A. L. (Eds.), Student affairs-a professions' heritage: Significant articles, authors, issues and documents (pp. 141-157). Alexandria, VA: American College Personnel Association Media Publication.

Blanchard, J. (2013). Institutional response to the changing legal environment regarding student safety: A multi-campus case sudy," Kentucky Journal of Higher Education Policy and Practice 2(2). Retrieved from http://uknowledge.uky.edu/kjhepp/vol2/iss2/5.

Blosnich, J. R., Kopacz, M. S., McCarten, J., \& Bossarte, R. M. (2014). Mental health and self-directed violence among student service members/veterans in postsecondary education. Journal of American College Health, DOI: 10.1080/07448481.2014.931282.

Bogust v. Iverson 102 N.W.2d 228 (1960).

Bradshaw v. Rawlings 612 F.2d 135 (1979).

Brownson, C., Drum, D. J., Smith, S. E., \& Burton Denmark, A. (2011). Differences in suicidal experiences of male and female undergraduate and graduate students. Journal of College Student Psychotherapy, 25(4), 277-294

Bryson, J. M. (2011). Strategic planning for public and nonprofit organizations: A guide to strengthening and sustaining organizational achievement ( $4^{\text {th }}$ ed.). San Francisco, CA: Jossey-Bass. 
Bublick, E. M. (2013). A concise restatement of torts ( $3^{\text {rd }}$ ed.). St. Paul MN: American Law Institute Publishers.

Burke, K. (2010). Issues in Illinois college campus safety: History and development of campus safety planning. Chicago, IL: Illinois Criminal Justice Information Authority.

Campus Security Enhancement Act, Illinois S. 2691. (2008).

Cantero, C. (2013a, December 29). Jackson Peebles, 21, had a habit of questioning authority and a 'deep desire to help humanity'. Kalamazoo Gazette. Retrieved from http://www.mlive.com/news/kalamazoo/index.ssf/2013/12/ kalamazoo_community_remembers_1.html

Cantero, C. (2013b, December 29). Western Michigan University revises policy related to students showing suicidal tendencies. Kalamazoo Gazette. Retrieved from http://www.mlive.com/news/kalamazoo/index.ssf/2013/12/western_michigan_uni versity_re_15.html

Castillo, L. G., \& Schwartz, S. J. (2013). Introduction to the special issue on college student mental health. Journal of clinical psychology, 69(4), 291-297.

Center for Mental Health Services, Substance Abuse and Mental Health Services Administration. (2007). Building bridges mental health on campus: Student mental health leaders and college administrators, counselors, and faculty in dialogue. Health \& Human Services Pub. No. SMA-4310. Rockville, MD: Health \& Human Services.

Clothier, R. C. 1931. College personnel principles and functions. In Saddlemire, G. L. \& Rentz, A. L. (Eds.), Student affairs-a professions' heritage: Significant articles, authors, issues and documents (pp. 9-20). Alexandria, VA: American College Personnel Association Media Publication.

Cloud, R.C. (2013). Safety and security on campus: Priority number one in higher education. West's Education Law Reporter, September 26, 2013, 457-474.

Colker, R. \& Grossman, P. (2014). The law of disability discrimination: 2014 supplement. New Providence, NJ: Lexis Nexis.

Cornell, D. (2010). Threat assessment in college settings. Change: The Magazine of Higher Learning, 42(1), 8-15.

Courtenay, W. H. (2011). Dying to be men: Psychosocial, environmental, and biobehavioral directions in promoting the health of men and boys. New York, NY: Routledge. 
Daddona, M. F. (2011). Peer educators responding to students with mental health issues. New Directions for Student Services, 2011(133), 29-39.

Davis, T., \& Laker, J. A. (2004). Connecting men to academic and student affairs programs and services. New directions for student services, 2004(107), 47-57.

DeJong, W. (2009). Problem analysis: The first step in prevention planning. Higher Education Center for Alcohol and Other Drug Abuse and Violence Prevention.

DeJong, W., \& Langford, L. M. (2002). A typology for campus-based alcohol prevention: Moving toward environmental management strategies. Journal of studies on alcohol and drugs, 2002(14), 140-147.

Delworth, U. (2009). The AISP model: Assessment-Intervention of Student Problems. New Directions for Student Services, 2009(128), 11-21.

Dernbach, J. C., Singleton II, R. V., Wharton, C. S., Ruhtenberg, J. M. \& Wasson, C. J. (2010). A practical guide to legal writing \& legal method $\left(4^{\text {th }}\right.$ ed.). New York, NY: Aspen Publishers.

Dixon v Alabama State Board of Education 294 F.2d 150 (1961).

Douce, L. A. \& Keeling, R. P. (2014). A strategic primer on college student mental health. Washington DC: American Council on Education.

Drum, D. J., Brownson, C., Denmark, A. B. \& Smith, S. E. (2009). New data on the nature of suicidal crises in college students: Shifting the paradigm. Professional Psychology Research and Practice, 40(3), 213-222.

Drum, D. J., \& Denmark, A. B. (2012). Campus suicide prevention: bridging paradigms and forging partnerships. Harvard Review of Psychiatry, 20(4), 209-221.

Dunkle, J. H. (2009). An introduction to the contemporary update. New Directions for Student Services, 2009(128), 5-10.

Dunkle, J. H., Silverstein, Z. B., \& Warner, S. L. (2008). Managing violent and other troubling students: The role of threat assessment teams on campus. Journal of College and University Law, 34(3), 585.

Dunn, W. N. (1981). Public policy analysis: An introduction. Englewood Cliff, N.J.: Prentice-Hall.

Dyer, S. G. (2008). Is there a duty?: Limiting college and university liability for student suicide. Michigan Law Review, 106(2008), 1379-1403. 
Eells, G. T., \& Rockland-Miller, H. S. (2010). Assessing and responding to disturbed and disturbing students: Understanding the role of administrative teams in institutions of higher education. Journal of College Student Psychotherapy, 25(1), 8-23.

Eisenberg, D., Downs, M. F., Golberstein, E., \& Zivin, K. (2009). Stigma and help seeking for mental health among college students. Medical Care Research and Review, 66(5), 522-541.

Eisenberg, D., Golberstein, E. \& Hunt, J. B. (2009). Mental health and academic success in college. The B.E. Journal of Economic Analysis \& Policy, 9(1), Article 40.

Eisenberg, D., Nicklett, E. J., Roeder, K., \& Kirz, N.E. (2011). Eating disorder symptoms among college students: Prevalence, persistence, correlates, and treatmentseeking. Journal of American College Health, 59(8), 700-707.

Eisman v. State of New York, 70 N.Y.2d 175, 511 N.E.2d 1128, 518 N.Y.S.2d 608 (1987).

Englar-Carlson, M., \& Kiselica, M. S. (2013). Affirming the strengths in men: A positive masculinity approach to assisting male clients. Journal of Counseling \& Development, 91(4), 399-409.

Enhancing Campus Safety and Security, Washington S. 6328. (2008).

Esteban v. Central Missouri State College 277 F.Supp. 649 (1967).

Farber, D. A., \& Sherry, S. (1993). Telling stories out of school: An essay on legal narratives. Stanford Law Review,45, 807-855.

First, P. F., Vines, J. E., Elue, C. A. \& Pindar, L. M. (2015). Researching legal topics from a policy studies perspective. In Permuth, S., Mawdsley, R. D. \& Silver, S. (Eds.), Research methods for studying legal issues in education $\left(2^{\text {nd }}\right.$ ed.). Cleveland, OH: Education Law Association.

Fossey, R. \& Moore, H. E. (2010). University tort liability for student suicide: The sky is not falling. Journal of Law \& Education, 39(2), 225-240.

Fox, J. A., \& Savage, J. (2009). Mass Murder Goes to College An Examination of Changes on College Campuses Following Virginia Tech. American Behavioral Scientist, 52(10), 1465-1485.

Furek v University of Delaware 594 A.2d 506 (1991).

Ganser, S. R., \& Kennedy, T. L. (2012). Where it all began: Peer education and leadership in student services. New Directions for Higher Education, 2012(157), 17-29. 
Goldston, D. B., Walrath, C. M., McKeon, R., Puddy, R. W., Lubell, K. M., Potter, L. B., \& Rodi, M. S. (2010). The Garrett Lee Smith memorial suicide prevention program. Suicide and Life-Threatening Behavior, 40(3), 245-256.

Grace, T. \& Smith, E.J. (2014, January 29). Self-endangering students: The public policy conundrum [Blog post]. Retrieved from https://www.naspa.org/rpi/posts/selfendangering-students-the-public-policy-conundrum

Grasgreen, A. (2011, December 6). OCR shift in harm to self rules has student affairs officials worried." Inside Higher Ed. Retrieved from http://www.insidehighered.com.

Grasgreen, A. (2014, January 2). Before a suicide OCR again tells colleges not to remove self-threatening students." Inside Higher Ed. Retrieved from http://www.insidehighered.com.

Gray, C. E. (2007). The university-student relationship amidst increasing rates of student suicide. The Law \& Psychology Review, 31(2007), 137. [iBook Reprint].

Griffin, O. R. (2009). Constructing a legal and managerial paradigm applicable to the modern-day safety and security challenge at colleges and universities. Saint Louis University Law Journal, 54, 241-267.

Gruttadaro, D., \& Crudo, D. (2012). College students speak: A survey report on mental health. Survey Report). Arlington, VA: National Alliance on Mental Illness.

Harper, S. R., Harris III, F., \& Mmeje, K. K. (2005). A theoretical model to explain the overrepresentation of college men among campus judicial offenders: Implications for campus administrators. NASPA journal, 42(4), 565-588.

Harris III, F. (2010). College men's conceptualizations of masculinities and contextual influences: Toward a conceptual model. Journal of College Student Development, 51(3), 297-318.

Harris III, F. \& Barone, R. P. (2011). The situation of men and situating men in higher education: A conversation about crisis, myth, and reality about college students who are male college students" In Laker, J. \& Davis, T. (Eds.), Masculinities in higher education: Theoretical and practical considerations (pp. 50-62). New York, NY: Routledge

Harris III, F., \& Edwards, K. E. (2010). College men's experiences as men: Findings and implications from two grounded theory studies. Journal of Student Affairs Research and Practice, 47(1), 43-62.

Harris III, F., \& Struve, L. (2009). Gents, jerks, and jocks: What men learn about masculinity in college. About Campus, 14(3), 2-9. 
Harris, R. (1973). Policy analysis and policy development. The Social Service Review, September(1973), 360-372.

Heilbrun, K., Dvoskin, J., \& Heilbrun, A. (2009). Toward preventing future tragedies: Mass killings on college campuses, public health, and threat/risk assessment. Psychological Injury and Law, 2(2), 93-99.

Hollingsworth, K. R., Dunkle, J. H., \& Douce, L. (2009). The high-risk (disturbed and disturbing) college student. New Directions for Student Services, 2009(128), 37 54.

Hu, S., Katherine, L., \& Kuh, G. D. (2011). Student typologies in higher education. New Directions for Institutional Research, 2011(S1), 5-15.

Hughes, S., White, R. J., \& Hertz, G. (2008). A new technique for mitigating risk on US college campuses. Journal of Higher Education Policy and Management, 30(3), 309-318.

Hunt, J. B., Watkins, D. \& Eisenberg, D. (2012). How do college campuses make decisions about allocating resources for student mental health?:Findings from key participant interviews. Journal of College Student Development, 56(6), 850-856.

Jablonski, M. A., McClellan, G. S., Zdziarski, E. L., Ambler, D., Barnett-Terry, R., Cook, L., ... \& Kindle, J. (2008). In search of safer communities: Emerging practices for student affairs in addressing campus violence. San Francisco, CA: Jossey-Bass.

Janin v. State of Iowa 617 N.W.2d 293 (2000)

Jed Foundation and Education Development Center Inc. A guide to campus mental health action planning. New York, NY: The Jed Foundation CampusMHAP and EDC, Inc.; 2011.

Jensen Arnett, J. (2007). Emerging adulthood: What is it, and what is it good for?. Child Development Perspectives, 1(2), 68-73.

Jodoin, E. C., \& Robertson, J. (2013). The public health approach to campus suicide prevention. New Directions for Student Services, 2013(141), 15-25.

Joffe, P. (2008). An empirically supported program to prevent suicide in a college student population. Suicide and Life-Threatening Behavior, 38(1), 87-103.

Kadison, R. \& DiGeronimo, T. F. (2004). College of the overwhelmed: The campus mental health crisis and what to do about it. San Francisco, CA: Jossey-Bass.

Kalchthaler, K. (2009). Wake-up call: Striking a balance between privacy rights and institutional liability in the student suicide crisis. The Review of Litigation, 29(4), 895-924. 
Kaslow, N. J., Garcia-Williams, A., Moffitt, L., McLeod, M., Zesiger, H., Ammirati, R., Berg, J. P., McIntosh, B. J., \& Members of the Emory Cares 4 U Coalition. (2012). Building and maintaining an effective campus-wide coalition for suicide prevention. Journal of College Student Psychotherapy, 26(2), 121-139.

Keller, E. W., Hughes, S., \& Hertz, G. (2011). A model for assessment and mitigation of threats on the college campus. Journal of Educational Administration, 49(1), 7694.

Kimmel, M. (2013). Angry white men: American masculinity at the end of an era. New York, NY: Nation Books.

Kimmel, M. \& Davis, T. (2011). Mapping guyland in college In Laker, J. \& Davis, T. (Eds.), Masculinities in higher education: Theoretical and practical considerations (pp. 3-15). New York, NY: Routledge.

Kirk, B. A. (1965). Identity crisis-1965: ACPA presidential address.” In Saddlemire, G. L. \& Rentz, A. L. (Eds.), Student affairs-a professions' heritage: Significant articles, authors, issues and documents (pp. 230-238). Alexandria, VA: American College Personnel Association Media Publication.

Klonsky, E. D. (2011). Non-suicidal self-injury in United States adults: prevalence, sociodemographics, topography and functions. Psychological medicine, 41(09), 1981-1986.

Koenig, R. (2015, February 13). Should colleges report suicidal students to their parents: A bill in Virginia would require it. The Chronicle of Higher Education. Retrieved from http://chronicle.com/article/Should-Colleges-Report/190017/.

Lake, P. F. (2008). Still waiting: The slow evolution of the law in light of the ongoing student suicide crisis. Journal of College \& University Law, 34, 253.

Lake, P. F. (2009). Beyond discipline: Managing the modern higher education environment. Bradenton, FL: Hierophant Enterprises, Inc.

Lake, P. F. (2011). Foundations of higher education law \& policy: Basic legal rules, concepts, and principles for student affairs. Washington, DC: NASPA.

Lake, P. F. (2013). The rights and responsibilities of the modern university: The rise of the facilitator university $2^{\text {nd }}$ ed. Durham, NC: Carolina Academic Press.

Laker, J. A. (2003). "Bad dogs: Rethinking our engagement of male students." In P.Brown (ed.), Men On Campus Series. Washington, D.C.: Standing Committee for Men, American College Personnel Association, 2003.

Laker, J. A. (2009). What should we be doing to reduce or end campus violence?. Journal of College and Character, 10(4). 
Lancaster, J. M. \& Waryold, D. M. (Eds.) (2008). Student conduct practice: The complete guide for student affairs professionals. Sterling, VA: Stylus Publishing, LLC

Lannon, P. (2014). Direct threat and caring for students at risk for self-harm: Where we stand now. NACUA Notes 12(8).

Lannon, P., \& Sanghavi, E. (2011). New Title II regulations regarding direct threat: Do they change how colleges and universities should treat students who are threats to themselves. NACUA Notes 10(1).

Lapp, D. J. (2010). The duty paradox: Getting it right after a decade of litigation involving the risk of student suicide." Washington \& Lee University School of Law Journal of Civil Rights \& Social Justice, 17(1), 29-58.

Leitch, D. (2015, April 14). Leitch passes student and older adult mental health bills in Illinois house. Retrieved from http://davidleitch.org.

Letarte, C. M. (2014). Keepers of the night: The dangerously important role of resident assistants on college and university campuses. Kentucky Journal of Higher Education Policy and Practice, 2(2), Article 4.

Levine, A. \& Dean, D. R. (2012). Generation on a tightrope: A portrait of today's college student. San Francisco, CA: Jossey-Bass.

Lewis, W. S., Schuster, S. K., \& Sokolow, B. A. (2012). Suicidal students, BITs and the direct threat standard. Whitepaper, National Center for Higher Education Risk Management. Retrieved from http://www.ncherm.org.

Lindo, J.M. Swensen, I.D. \& Waddell, G.R. (2011). Are big-time sports a threat to student achievement? NBER Working Paper No. 17677. Cambridge, MA: National Bureau of Economic Research.

Livingston, W. G., Scott, D. A., Havice, P. A., \& Cawthon, T. W. (2012). Social Camouflage: Interpreting Male Student Veterans' Behavior for Residence Life Professionals. Journal of College and University Student Housing, 39(1), 176185.

Lowery, J. W. (1998). Institutional policy and individual responsibility: Communities of justice and principle. New Directions for Student Services, 1998(82), 15-27.

Lowery, J. W. (2008). Laws, policies, and mandates. In Lancaster, J. M. \& Waryold, D. M. (Eds.), Student conduct practice: The complete guide for student affairs professionals (pp. 71-96). Sterling, VA: Stylus Publishing LLC. 
Ludeman, R. B. (2004). Arrested emotional development: Connecting college men, emotions, and misconduct. New directions for student services, 2004(107), 7586.

Lugg, E. T. (2012). EAF 578 legal basis of higher education lecture on liability. Summer 2012.

Lugg, E. T. (2014). EAF 512 Lecture on steps of policy analysis. January 2014.

MacKean, G. (2011). Mental health and well-being in post-secondary education settings. Canadian Association of College and University Student Services.

Mahoney v Allegheny College No. 892-2003 Crawford County (2005).

Massie, A. M. (2008). Suicide on campus: The appropriate legal responsibility of college personnel Marquette Law Review 91(2008), 625.

Massie, A.M. (2010). Symposium: Introduction. Washington \& Lee University School of Law Journal of Civil Rights \& Social Justice, 17(1), 1-11.

McAnaney, K. (2008). Finding the proper balance: Protecting suicidal students without harming universities. Virginia Law Review, 94(2008), 197-246.

McClellan, G. S., Eklund-Leen, S. J., Gatti, R. M., \& Kindle, J. L. (2009). Will it work both here and there? The AISP model in various institutional contexts. New Directions for Student Services, 2009(128), 77-87.

McGreevy, P. (2014a, June 24). New gun control bills introduced in response to Isla Vista massacre. LA Times (Online Edition).

McGreevy, P. 2014b, June 24). Senate panel approves bill responding to Isla Vista massacre. LA Times (Online Edition).

McNicholl, R. J. (2014, October). Suicide prevention on college campuses: Everyone has a role. Keynote presentation at the Eastern Illinois University Thomas A. Bonine Suicide Prevention Conference, Charleston, IL

Moore, H. E. (2007). University liability when students commit suicide: Expanding the scope of the special relationship. Indiana Law Review, 40(2007), 423-451.

Mullins v. Pine Manor College 389 Mass. 47; 449 N.E.2d 331(1983).

Meunier, L. H., \& Wolf, C. R. (2006). Mental health issues on college campuses. Health Law Journal, 11(2), 42-52. 
Mitchell, S. L., Darrow, S. A., Haggerty, M., Neill, T., Carvalho, A., \& Uschold, C. (2012). Curriculum infusion as college student mental health promotion strategy. Journal of College Student Psychotherapy, 26(1), 22-38.

Nero v. Kansas State University 253 Kan. 567, 861 P.2d 768 (1993).

Nordberg, S. S., Hayes, J. A., McAleavey, A. A., Castonguay, L. G., \& Locke, B. D. (2013). Treatment Utilization on College Campuses: Who Seeks Help for What?. Journal of College Counseling, 16(3), 258-274.

Nott v. The George Washington University No. 05-8503 Superior Court of the District of Columbia (2005).

Novotney, A. (2014). Students under pressure: College and university counseling centers are examining how best to serve the growing number of students seeking their services. APA Monitor, 45(8) p. 36. Retrieved from http://www.apa.org/printthis.aspx.

O'Connor, T. (2011). Program evaluation and policy analysis. Megalinks in Criminal Justice. Retrieved from http://drtomoconnor.com/3760/3760lect08.htm.

OCR Letter to Woodbury University (June 29, 2001) Complaint Number 09-00-2079.

OCR Letter to Guilford College (March 6, 2003) Complaint Number 1-1-02-2003.

OCR Letter to Bluffton University (December 22, 2004) Complaint Number 15-04-2042.

OCR Letter to Marietta College (March 18, 2005) Complaint Number 15-04-2060.

OCR Letter to Spring Arbor University (December 16, 2010) Docket Number 15-102098.

OCR Letter to the State University of New York at Purchase (January 14, 2011) Case Number 02-10-2181.

OCR Letter to St. Joseph's College (January 24, 2011) Case Number 02-10-2171.

Oxford Dictionary Online. http://www.oxforddictionaries.com/us/ definition/ american_english/ perfect-storm.

Parent, M. C., \& Moradi, B. (2011). His biceps become him: a test of objectification theory's application to drive for muscularity and propensity for steroid use in college men. Journal of Counseling Psychology, 58(2), 246.

Parental Notification of Student's Suicidal Tendencies, Virginia S.B. 1122. (2015). 
Paterson, B. \& Gregory, D. (2013). The evolution of student discipline In Lancaster, J. M. \& Waryold, D. M. (Eds.), Student conduct practice: The complete guide for student affairs professionals (pp. 27-30). College Station, TX: Association for Student Conduct Administration.

Patterson, M. D. (Ed.). (1984). Thomas Jefferson: Writings. The Library of America.

Pavela, G. D. (2006). Should colleges withdraw students who threaten or attempt suicide?." American College Health Association 54(6), 367-371.

Pavela, G. (2008). Creating a college threat assessment program. ASJA Law and Policy Report, 277.

Pavela, G. (2010). College suicide: A law and policy perspective. Washington and Lee Journal of Civil Rights and Social Justice, 17(1): 13-28.

Pavela, G. (2012). College suicide: A law and policy perspective. The Policy Report, 2012 Outline.

Penven, J. C., \& Janosik, S. M. (2012). Threat Assessment Teams: A Model for Coordinating the Institutional Response and Reducing Legal Liability When College Students Threaten Suicide. Journal of Student Affairs Research and Practice, 49(3), 299-314.

Piet DeLaTorre, C. (2011). An implementation analysis of threat assessment policies in public universities and community colleges in central texas: A post virginia tech incident assessment. (The University of Texas at Dallas). ProQuest Dissertations and Theses, 185. Retrieved from http://search.proquest.com/docview/864734353?accountid=14982. (864734353).

Public Institutions of Higher Education Safety, Virginia H. 1449. (2008).

Rasmussen, C. \& Johnson, G. (2008). The ripple effect of Virginia Tech: Assessing the nationwide impact on campus safety and security policy and practice. Midwestern Higher Education Compact.

Restatement (Second) of Torts. (1965). St Paul, MN: American Law Institute Publishers.

Rodríguez, M. D. C. F., \& Huertas, I. B. (2013). Suicide prevention in college students: A collaborative approach. Revista interamericana de psicologia= Interamerican journal of psychology, 47(1), 53-60.

Romantz, D. S. \& Vinson, K. E. (2009). Legal analysis: The fundamental skill. Durham, NC: Carolina Academic Press.

Rosenfield, S., \& Mouzon, D. (2013). Gender and mental health. In Handbook of the sociology of mental health (pp. 277-296). Springer Netherlands. 
Roy, L. (2009). No right to remain silent: The tragedy of Virginia Tech. Random House Digital, Inc.

Roy, L. (2010). Insights gleaned from the tragedy at Virginia Tech. Washington \& Lee University School of Law Journal of Civil Rights \& Social Justice, 17(1), 93-123.

Rudolph, F. (1990). The American college and university: A history. Athens, GA: University of Georgia Press.

Russo, P. J. (2006). Legal research: The traditional method. In Permuth, S. \& Mawdsley, R. D. (Eds.), Research methods for studying legal issues in education. Dayton $\mathrm{OH}$ : Education Law Association.

Russo, P. J. (2015). Legal research: The traditional method. In Permuth, S., Mawdsley, R. D. \& Silver, S. (Eds.), Research methods for studying legal issues in education ( $2^{\text {nd }}$ ed.). Cleveland, OH: Education Law Association.

Salzer, M. S. (2012). A comparative study of campus experiences of college students with mental illnesses versus a general college sample. Journal of American College Health, 60(1), 1-7.

Sandeen, A. (2009). A senior student affairs officer's perspective on the AISP model. New Directions for Student Services, 2009(128), 55-58.

Schieszler v Ferrum College 236 F. Supp. 2d 602, 609 (2002).

Scott, R. A. (2008). The challenges facing higher education in America today. Invited Keynote Address, Luncheon Roundtable. Naples, FL: February 28, 2008.

Shang, P. \& Barkis, M. (2009). The AISP model on increasingly diverse campuses. New Directions for Student Services, 2009(128), 69-76.

Sharkin, B. (2006). College students in distress: A resource guide for faculty, staff, and campus community. New York: The Haworth Press.

Sheehy, J. \& Commerford, M. (2006). Eating disorders. In Grayson, P. A. \& Meilman, P. W. (Eds.), College mental health practice (pp. 261-280). New York, NY:Routledge.

Shin v Massachusetts Institute of Technology No. 020403, 2005 WL 1869101 (2005).

Smits, J. M. (2012). The mind and method of the legal academic. Cheltenham, UK: Edward Elgar.

Sokolow, B. A. (2008). Stop the Madness: How universities should be responding to school shootings. National Center for Higher Education Risk Management article. Retrieved from http://www.ncherm.org/pdfs/article_STOP_THE_MADNESS.pdf. 
Sokolow, B. A. \& Hughes, S. (2008). Risk mitigation through the NCHERM behavioral intervention and threat assessment model. Whitepaper. National Center for Higher Education Risk Management. Retrieved from http://www.ncherm.org/pdfs/2008whitepaper.pdf.

Sokolow, B. A., Lewis, W.S., Keller, J. A., \& Daly, A. (2008). College and university liability for violent campus attacks. Journal of College and University Law, 34(2), 319-347. Retrieved from http://www.ncherm.org.

Sood, A. B. \& Cohen, R. (2015). The Virginia Tech massacre: Strategies and challenges for improving mental health policy on campus and beyond. Oxford University Press.

Stoner, E. N. (2004). Navigating Past the Spirit of Insubordination: A Twenty-First Century Model Student Conduct Code with a Model Hearing Script. Journal of College and University Law 31(2004), 1-78.

Stuart, S. P. (2012). "Hope and despondence": Emerging adulthood and higher education's relationship with its nonviolent mentally ill students. Journal of College \& University Law, 38, 319-379.

Student Optional Disclosure of Private Mental Health Act, Illinois H.B. 3599, (2015).

Substance Abuse and Mental Health Services Administration. (2015). 2015 campus suicide prevention grant. Retrieved from http://www.samhsa.gov/grants/grantannouncements.

Sulkowski, M. L., \& Joyce, D. J. (2012). School psychology goes to college: The emerging role of school psychology in college communities. Psychology in the Schools, 49(8), 809-815

Swanbrow Becker, M. A., \& Drum, D. J. (2015). The influence of suicide prevention gatekeeper training on resident assistants' mental health. Journal of Student Affairs Research and Practice, 52(1), 76-88.

Tang, M. O., Oliffe, J. L., Galdas, P. M., Phinney, A., \& Han, C. S. (2014). College men's depression-related help-seeking: a gender analysis. Journal of Mental Health, 23(5), 219-224.

Tarasoff v. Regents of the University of California 17 Cal. 3d 425, 551 P.2d 334 (1976).

Taub, D. J., \& Servaty-Seib, H. L. (2011). Training resident assistants to make effective referrals to counseling. The Journal of College and University Student Housing, $37(2), 11-25$. 
Taub, D. J., Servaty-Seib, H. L., Miles, N., Lee, J. Y., Wachter Morris, C. A., Prieto Welch, S. L., \& Werden, D. (2013). The impact of gatekeeper training for suicide prevention on university resident assistants. Journal of College Counseling, 16(1), 64-78.

Thombs, D. L., Gonzalez, J. M. R., Osborn, C. J., Rossheim, M. E., \& Suzuki, S. (2014). Resident assistant training program for increasing alcohol, other drug, and mental health first-aid efforts. Prevention Science, 1-10.

Tripp, P. A. (1968). Student personnel workers: Student development experts of the future. In Saddlemire, G. L. \& Rentz, A. L. (Eds.), Student affairs-a professions' heritage: Significant articles, authors, issues and documents (280-283).

Alexandria, VA: American College Personnel Association Media Publication.

University of Illinois. (n.d.). Kognito training. Retrieved from http://counselingcenter.illinois.edu/emergency/kognito-risk-suicide-preventiontraining and https://ui.kognito.com.

University of Illinois. (n.d.). Suicide policy. Retrieved from http://counselingcenter.illinois.edu/outreach-consultation-prevention/ outreachconsultation-teams/suicide-prevention-program/suicide.

U.S. Department of Education. (2011). College completion tool kit. Washington, D.C.

Van Brunt, B. \& Lewis, W. S. (2014). A faculty guide to addressing disruptive and dangerous behavior. New York, NY: Routledge.

Virginia Acts of Assembly 2015 Session, Chapter 716 (2015).

Vogel, D. L., Wester, S. R., Hammer, J. H., \& Downing-Matibag, T. M. (2014). Referring men to seek help: The influence of gender role conflict and stigma. Psychology of Men \& Masculinity, 15(1), 60.

Waryold, D. M. (2013). The student conduct administrator" In Waryold, D. M. \& Lancaster, J. M. (Eds.), The state of student conduct current forces and future challenges: Revisited (pp. 27-30). College Station, TX: Association for Student Conduct Administration.

Waryold, D. M., \& Lancaster, J. M. (2008). The professional philosophy of student conduct administration. In Lancaster, J. M. \& Waryold, D. M. (Eds.), Student Conduct Practice: The Complete Guide for Student Affairs Professionals (p. 613).

Waryold, D. M. \& Lancaster, J. M. (Eds.). (2013). The state of student conduct current forces and future challenges: Revisited. College Station, TX: Association for Student Conduct Administration. 
Watkins, D. C., Hunt, J. B., \& Eisenberg, D. (2011). Increased demand for mental health services on college campuses: Perspectives from administrators. Qualitative Social Work, 11(3), 319-337.

Western Illinois University. (n.d.). Syllabus policy. Retrieved from http://wiu.edu/policies/syllabus.php.

Whitlock, J., Muehlenkamp, J., Purington, A., Eckenrode, J., Barreira, P., Baral Abrams, G., ... \& Knox, K. (2011). Nonsuicidal self-injury in a college population: General trends and sex differences. Journal of American College Health, 59(8), 691-698.

Yousaf, O., Popat, A., \& Hunter, M. S. (2015). An investigation of masculinity attitudes, gender, and attitudes toward psychological help-seeking. Psychology of Men \& Masculinity, 16(2), 234-237. 